Article

\title{
The Influence of Energy Certification on Housing Sales Prices in the Province of Alicante (Spain)
}

\author{
Maria-Francisca Cespedes-Lopez ${ }^{(}$, Raul-Tomas Mora-Garcia * ${ }^{(0)}$, V. Raul Perez-Sanchez ${ }^{\circledR}$ and \\ Pablo Marti-Ciriquian (1) \\ Building Sciences and Urbanism Department, University of Alicante, 03690 San Vicente del Raspeig, Alicante, \\ Spain; paqui.cespedes@ua.es (M.-F.C.-L.); raul.perez@ua.es (V.R.P.-S.); pablo.marti@ua.es (P.M.-C.) \\ * Correspondence: rtmg@ua.es
}

Received: 9 September 2020; Accepted: 10 October 2020; Published: 13 October 2020

check for updates

\begin{abstract}
This work examines the implementation of energy labelling by the residential real estate sector. First, it considers the interest by real estate sellers in not publishing energy certification information, and then, it quantifies the impact of the housing's energy certification on the asking price. The results are compared with those obtained from other studies conducted in distinct European countries. The study's final sample was collected, including information from 52,939 multi-family homes placed on the real estate market in the province of Alicante (Spain). One-way analysis of variance (ANOVA) was used, as well as an ordinary least squares regression model. This study highlights the fact that, in the current market, owners and sellers have no incentive to reveal the energy certification, since this permits them to sell homes with low energy ratings at prices similar to those of more energy efficient homes. In addition, it was found that homes with better energy ratings (letters A and B) are not sold at higher prices than homes with other rating letters, unlike the case of other European countries that were examined.
\end{abstract}

Keywords: energy performance certificate (EPC); hedonic pricing method; real estate market; property prices; Alicante

\section{Introduction}

High energy consumption by buildings is a global issue, and the implementation of policies promoting energy performance improvement measures is challenging. According to Hirsch, et al. [1], the European Union (EU) has taken a leadership role in this area, implementing directives [2-5] and financing various energy efficiency research and innovation projects (Project SP-0165/CEENEREPC [6], EPLABEL [7], ENPER EXIST [8], SHARE [9], ASIEPI [10], RentalCal [11], RESPOND [12], CRREM [13], among others).

The European directives [2,3] establish a mandatory certification system, the so-called "ABCDEFG qualification", which rates buildings based on their energy efficiency, similar to the classification used for household appliances. In addition, these directives require the publication of an energy performance certificate (EPC), to be included in the documentation supplied by owners to purchasers or renters. These policies are an attempt to offer increased transparency and information to consumers, to assist in decision-making related to property purchase or rental.

In Spain, these directives result from the enforcement of a series of decrees $[14,15]$ requiring energy certification and the presentation of an energy efficiency label in properties placed on the rental or sales market. On the other hand, the level of compliance with the directive varies depending on the specific case. In the case of real estate sales, compliance is significant, given that certification documentation is required by the notary public when formalizing a deed of sale. In the case of publishing energy 
certification in advertisements for sales or rentals, there is a high level of non-compliance with the directive [16].

With regard to the financed projects, studies [6,17] have analyzed the relationship between the certification system and the property's value, in an attempt to determine whether or not properties with higher sales or rental prices correspond to those that are more energy efficient. Mudgal, et al. [6] confirmed a positive relationship between the information published on energy performance and the property's value. Taltavull de La Paz, et al. [17] obtained contrary results, that is, homes that were more energy efficient did not have higher sales prices than other homes with poorer energy qualifications. However, these are not the only studies that have been conducted with this objective and that have obtained contradictory results. In studies carried out in Denmark [18], France [19,20], the Netherlands [21,22], Ireland [23], Italy [24], the United Kingdom [25-27] or Spain [16,28], it has been found that homes having better ratings (letters A, B or C) have higher market prices than less efficient homes (letters D, E, F or G). On the other hand, studies conducted in Ireland [29], Norway [30] and Spain $[16,31]$ have obtained unexpected results. A thorough review of the literature on EPC and housing prices was carried out by Cespedes-Lopez, et al. [32].

This study has two main objectives. The first is to consider the interest by real estate sellers in not publishing energy qualifications. The second is to determine the economic impact of energy qualifications on the asking prices of homes sold on the real estate market in the province of Alicante (Spain), so that it is possible to compare the results of this study with past works.

The first hypothesis proposed in the study $\left(\mathrm{H}_{1}\right)$, is that housing that do not publish the energy qualification are sold at prices that are similar to housing having high energy qualifications. The second hypothesis $\left(\mathrm{H}_{2}\right)$ states that housing that published their energy qualifications have higher sales prices than those that do not publish them. The third hypothesis $\left(\mathrm{H}_{3}\right)$ is that housing with high energy qualifications will be offered at higher prices than less efficient homes.

The housing market serves major economic and social functions. Firstly, this sector is very significant in the economy of developed countries. Secondly, it determines the access of households to housing. The real estate crisis in the Spanish residential market was severe, resulting in a dramatic decline in housing prices. However, following the crisis, from 2014 until late 2018, real estate sales prices increased by $31 \%$, mainly in the second-hand segment. During this period, foreigners who were not Spanish residents represented approximately $20 \%$ of all purchases, with a greater majority centering in the Mediterranean and the islands [33]. On a national level, $71.7 \%$ of all housing is intended for primary use, whereas in Alicante, it is $58.0 \%$, with $25.6 \%$ of all housing being used as second residences (as compared to the $14.6 \%$ national rate). The main tenancy regime is ownership (85.4\%) as opposed to rental (14.6\%). The building stock consists mainly of collective housing (buildings), $68-77 \%$ of the total, as compared to single-family homes, which only represent $23-32 \%$. See Table A1 of the Appendix A for more details on these statistics.

If the data on real estate transactions from 2019 is analyzed [34], on a national level, $41.7 \%$ of the housing transactions were carried out by Spanish residents, as compared to $26.1 \%$ in the Alicante province. The Alicante market has a significant international exposure, being a destination for foreigners, participating in $23.2 \%$ of all of the province's transactions. In the Valencian community, in a breakdown of the number of real estate transactions per province, it is seen that Alicante has a more dynamic market than Valencia and Castellón (Figure 1a). Analyzing the real estate transactions in terms of purchaser place of residence (Figure 1b), it may be observed that the volume of transactions by foreign residents in the province of Alicante, except during the second quarter of 2020 where data is provisional $(*)$, exceeds $45 \%$. In the other two provinces, the values are approximately $20 \%$. This difference highlights a distinct behavior of the real estate market in the Alicante province as compared to the other two Valencia provinces, which serves as a motivation for its consideration in this work. 


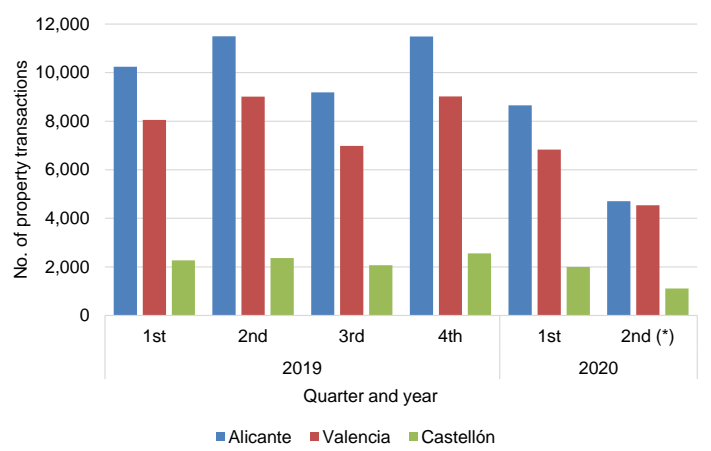

(a)

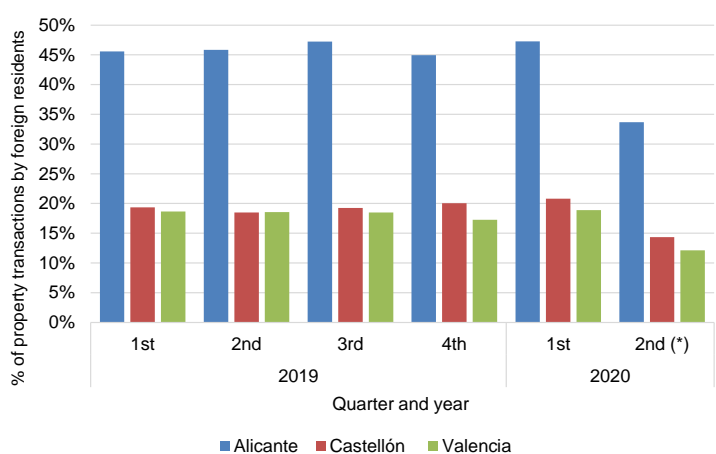

(b)

Figure 1. (a) Number of real estate transactions by province; (b) number of real estate transactions by foreign residents in the Valencian community.

In terms of energy and climate (Figure 2), Spain's climatic diversity should be considered (CTE-HE 2013) [35], since it has always, and continues to, significantly condition the energy characteristics of the building stock. In Spain, within the same region, it is possible to find mild climates in Mediterranean coastal areas and continental climates with more extreme temperatures, as occurring in the Alicante province. This characteristic may even be found in cases in which the separation between climate zones is barely $70 \mathrm{~km}$, as occurs in the coast and the interior of the province, where mountain chains exceeding $1000 \mathrm{~m}$ in height are found. This climatic diversity leads to a distinct energy allocation of the buildings. Therefore, electricity is frequently used to heat and cool buildings on the Mediterranean coast, via heating pumps, whereas in the interior, it is more common to find buildings that are heated with community or individual heating systems using natural gas. As for the heating system used in the Valencian community [36], centralized or collective systems represent only $4.6 \%$ (10.56\% on a national level), while heating in the entire housing represents only $27.4 \%$ (as compared to $46.30 \%$ across Spain). In this province, it is common to use small heating devices for single rooms (54.2\%) or even, to have no heating devices at all (13.8\%). (see Table A1 of the Appendix A).

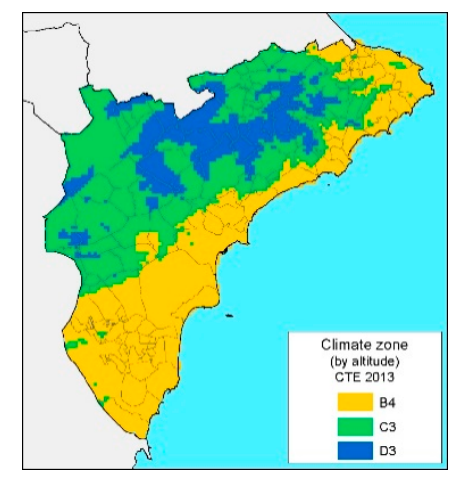

(a)

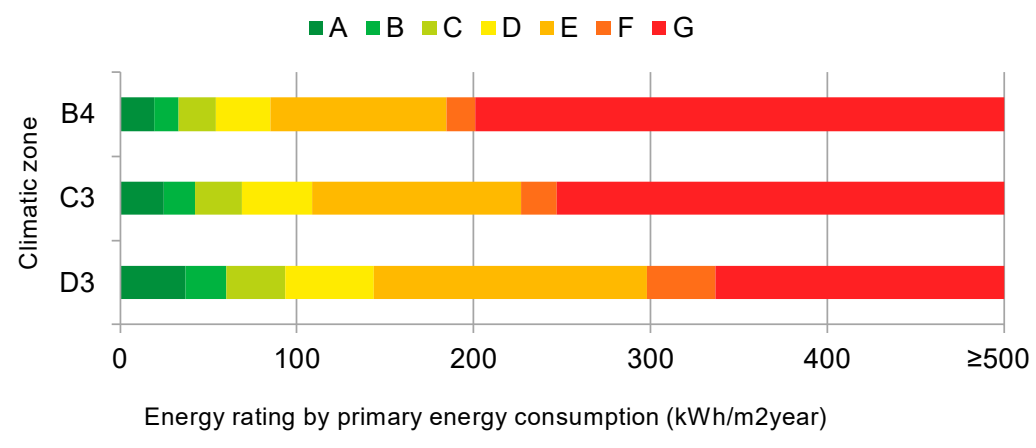

(b)

Figure 2. (a) Climatic areas in the Alicante province; (b) energy rating by primary energy consumption $\left(\mathrm{kWh} / \mathrm{m}^{2}\right.$ year) for homes and buildings, according to climate zone, obtained from the CE3 programme and the CTE 2013 regulations.

The document is organized as follows: In the second section, the materials and methods are described, detailing the sources used and the database generated. The third section offers the results. The fourth section contains the discussion and finally, a summary of the conclusions obtained is presented. 


\section{Materials and Methods}

First, an analysis of variance (ANOVA) was proposed to determine whether or not differences exist in the offered prices, based on the published energy qualification. To examine the economic premiums of the housing based on energy qualification, an ordinary least squares regression model has been proposed. For this, various estimates have been made, based on the reference used in the housing's energy qualification (letter or group of letters).

Hedonic regression models have been used since the "New Approach to Consumer Theory" created by Lancaster [37]. Ridker and Henning [38] used ordinary least squares (OLS) for the first time in the context of the housing market. Authors such as Zietz, et al. [39] indicate that hedonic regression analysis is normally used to identify the marginal effect of a set of characteristics on the housing price. For the case of heterogeneous goods such as housing, hedonic methodology permits the estimation for the contribution of each characteristic on the price [40]. Currently, this methodology is the most commonly used to determine the economic premium generated by distinct characteristics. In Table A2 of the Appendix A, the variables that are the most commonly used by other authors to determine housing price are shown.

\subsection{Population and Sample}

The database consists of multi-family housing placed on the market in the province of Alicante (Valencian Community, Spain) see Figure 3. The interest and selection criteria were based on the significant activity of the construction sector in this area, which is the third province in the country in terms of having the largest number of property transactions (purchases), after Barcelona and Madrid. On the other hand, it is fourth in terms of number of unsubsidized housing sales initiated in 2017 [41].

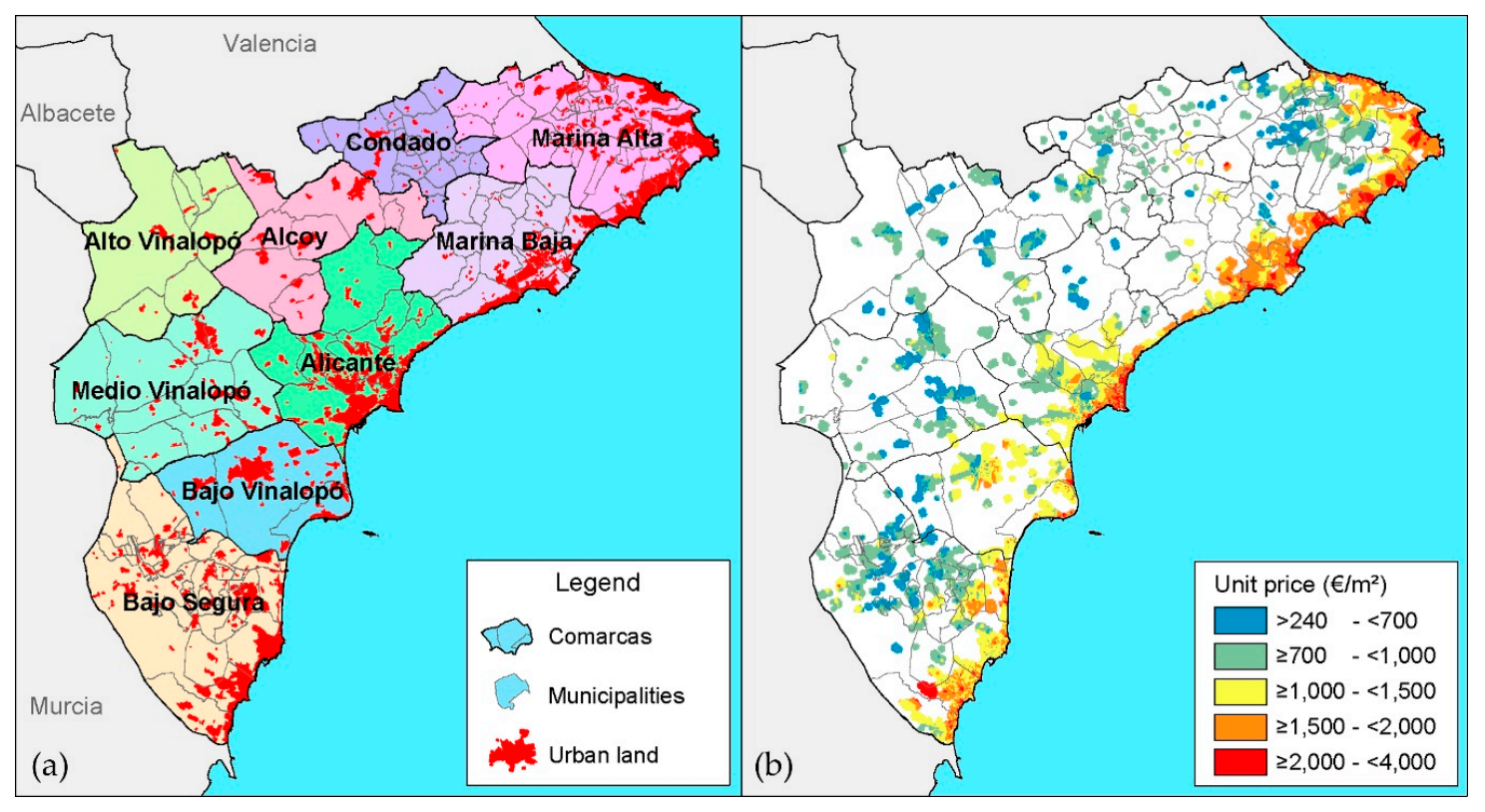

Figure 3. (a) Map of the province of Alicante with the delimitation of the comarcas, municipal boundary delimitation and the stain of continuous urban land; (b) kernel density map with unit prices of multi-family houses (euros $/ \mathrm{m}^{2}$ ).

The study sample consists of housing properties that were placed on the market via the idealista.com real estate portal between June 2017 and May 2018. During this period, information was collected on 97,279 properties placed on the market, extracting data on the characteristics of the housing and buildings. Subsequently, via GIS, information was provided on the location, neighborhood and market, obtained from other information sources. The final database was subject to a univariate analysis of outliers, discarding properties that differed by more or less than three standard deviations in their 
respective variables ( $Z$ scores). This process was performed on the following variables: natural log of the property price, age, height in stories, constructed surface area, number of bedrooms and bathrooms. To identify the multivariate atypical cases, the regression model was calibrated by calculating the Mahalanobis distance (MD) and its statistical significance, discarding any files in which the significance was less than 0.001, in accordance with Hair, et al. [42]. Finally, those properties having missing data on any of the variables that were subject of the analysis were discarded, obtaining a final sample of 52,939 observations, of which, 9194 included information on energy qualification.

The sample's representativeness was verified via the Equation (1), designed for large or infinite populations when the exact size of the units making it up is unknown [43].

$$
n=\frac{\left(z_{\alpha / 2}\right)^{2} * p *(1-p)}{E^{2}}
$$

where: $z_{\alpha / 2}$ is the $Z$ score corresponding to the selected level of confidence, $p$ is the probability that event $p$ takes place (when not having sufficient information the least favorable value is assigned, $p=$ 0.50 ), and $E$ is the maximum admissible error or the maximum error that is committed in the sample.

Using a $95 \%$ confidence level $\left(z_{\alpha / 2}=1.96\right)$, a probability of $p=0.50$ and samples sizes of $n=$ 52,939 and $n=9194$, clearing $E$, a maximum estimated error of $0.4 \%(0.004)$ and $1.0 \%(0.010)$ were obtained, respectively, ensuring the high statistical precision of the sample.

\subsection{Sources of Information}

The main source of information is the real estate portal idealista.com, which publishes the asking prices along with the characteristics of the housing and the building in which it is located. Other studies have also considered real estate portals with the same objective, given the lack of official information available [44-48], with the real estate asking prices being a suitable substitute for the transaction prices [49]. In Figure 4, the distribution of energy certificates in the Alicante province is shown, as well as details on the province's two largest cities (Alicante and Elche).
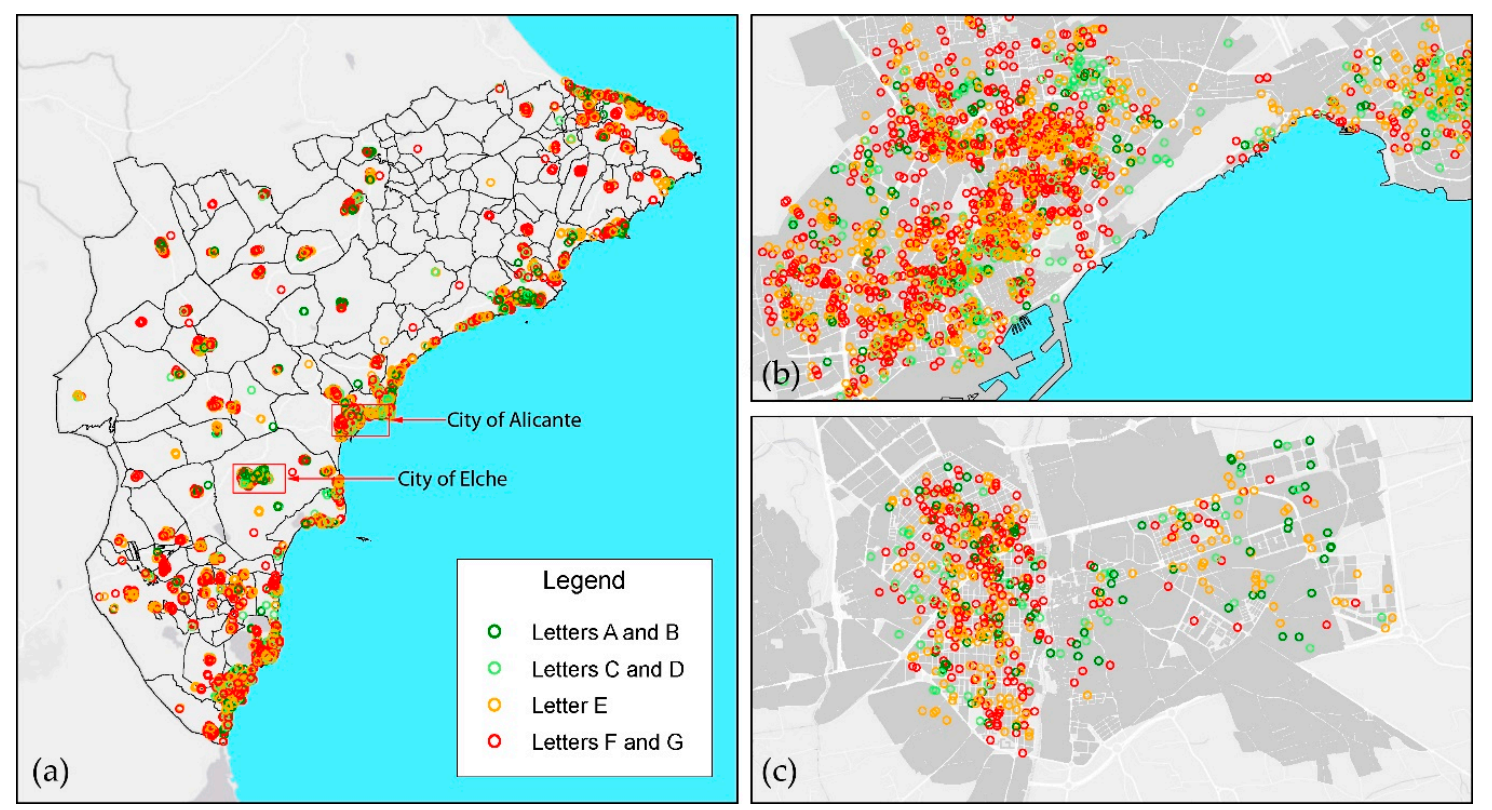

Figure 4. (a) Energy certificate distribution in the Alicante province; (b) detail of Alicante city; (c) detail of Elche city.

Other sources used have included the General Land Registry Directorate (DGC), the National Statistics Institute (INE), the National Geographic Institute (IGN), the Department of Education, Culture and Sports (CECD), the Directorate General for Planning, Assessment and Patient Care of the Health 
Department (DGOEAPCS) and the Basic Document on Energy Saving from the Technical Code for Buildings (CTE-DB-HE).

Based on the alphanumeric and vectorial information from the DGC [50,51], a raster map was created to estimate the age of the housing (Figure 5a) and the ratio of the constructed surface area in the proximity of each building (150 $\mathrm{m}$ around the same). With population census and INE housing data [36] and IGN mapping, the type of occupation was collected for each census tract (vacant, main and secondary), as well as the type of tenancy regime (rented, mortgaged and owned) and the population's sociodemographic characteristics (dependency, ageing, foreign population and education level). With the information from the CECD and the DGOEAPCS, distances between the housing and the public services or the following points of interest were calculated: hospitals, health centers, pharmacies, schools (Figure 5b), as well as proximity to the coast. Distances have been calculated by network, that is, based on the length of origin and destination using a layout of pre-established streets and intersections, simulating the reality of the urban network. The CTE-DB-HE is used to determine the climatic zone of the town where the property is located (climatic severity of summer and winter seasons) $[35,52]$.

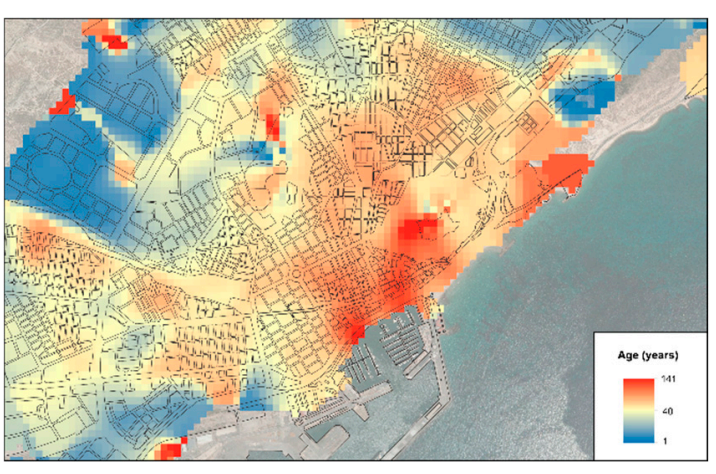

(a)

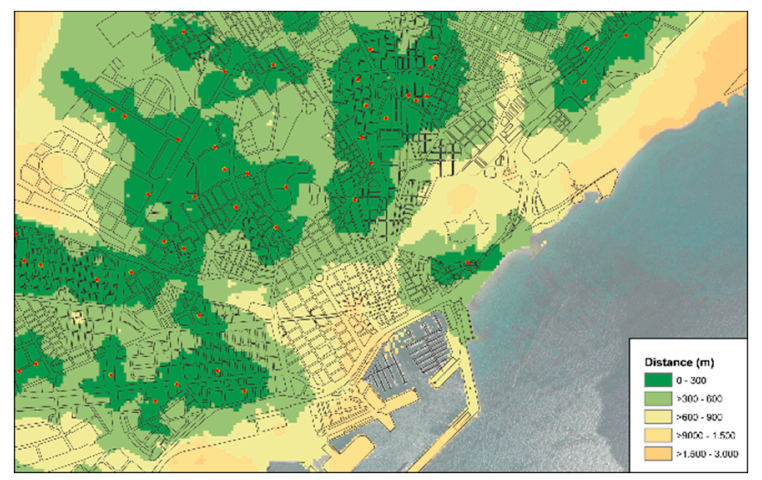

(b)

Figure 5. Maps of the city of Alicante: (a) age of the buildings and (b) distance from primary and secondary schools.

\subsection{Data}

Variables were selected based on a literature review (see Table A2 of the Appendix A). Based on the information received, 63 variables were obtained, as summarized in Table 1 . The variables are ordered based on five categories: Housing characteristics (A), Building characteristics (B), Location characteristics (C), Neighborhood characteristics (D), and Market characteristics (E). The unit with which each variable has been measured is also indicated, as well as a brief description of the same and verification as to whether or not it was used in model estimation.

Table 1. Set of variables that make up the study, with their units and description.

\begin{tabular}{|c|c|c|c|c|c|c|}
\hline Category & Characteristics & Variable & Unit & Description of the Variable & Used & Expected Sign \\
\hline \multirow{5}{*}{$\begin{array}{l}\text { Dwelling } \\
\text { characteristics } \\
\text { (A) }\end{array}$} & Age & A_age & numerical & $\begin{array}{l}\text { Age of the building (years), } \\
\text { number of years that have } \\
\text { passed since it was built. }\end{array}$ & Yes & - \\
\hline & \multirow[t]{3}{*}{ Size } & A_area_m2 & numerical & $\begin{array}{l}\text { Built dwelling surface (sqm), } \\
\text { gross square meters of the } \\
\text { dwelling. }\end{array}$ & Yes & + \\
\hline & & A_bedrooms & numerical & $\begin{array}{l}\text { Number of bedrooms in the } \\
\text { dwelling. }\end{array}$ & Yes & - \\
\hline & & A_bathrooms & numerical & Number of bathrooms. & Yes & + \\
\hline & Extras & A_wardrobe & dummy & $\begin{array}{l}\text { Availability of built-in } \\
\text { wardrobes }(=1) \text {. }\end{array}$ & Yes & + \\
\hline
\end{tabular}


Table 1. Cont

\begin{tabular}{|c|c|c|c|c|c|c|}
\hline Category & Characteristics & Variable & Unit & Description of the Variable & Used & Expected Sign \\
\hline & & A_air_cond & dummy & $\begin{array}{l}\text { Availability of air } \\
\text { conditioning }(=1)\end{array}$ & Yes & + \\
\hline & & A_terrace & dummy & $\begin{array}{l}\text { Availability of balcony or } \\
\text { terrace }(=1) .\end{array}$ & Yes & + \\
\hline & Floor & A_floor & numerical & $\begin{array}{l}\text { Floor the dwelling was } \\
\text { located on within the } \\
\text { building. }\end{array}$ & Yes & + \\
\hline & \multirow{3}{*}{ Status } & \multicolumn{2}{|c|}{ A_new_constructiondummy } & $\begin{array}{c}\text { Newly build housing that can } \\
\text { be: a project, under } \\
\text { construction, or less than } 3 \\
\text { years old. }\end{array}$ & Yes & + \\
\hline & & A_state_to_reform & dummy & Requires refurbishment. & Yes & - \\
\hline & & A_good_condition & dummy & $\begin{array}{l}\text { Classification that the seller } \\
\text { assigns to the state of the } \\
\text { dwelling, such as "good". }\end{array}$ & Reference & \\
\hline & \multirow{4}{*}{ Typology } & A_flat & dummy & \multirow{4}{*}{$\begin{array}{l}\text { Indicates whether the } \\
\text { property has this typology: } \\
\text { Flat or apartment, studio flat, } \\
\text { penthouse, duplex }\end{array}$} & Reference & \\
\hline & & A_studio_flat & dummy & & Yes & - \\
\hline & & A_penthouse & dummy & & Yes & + \\
\hline & & A_duplex & dummy & & Yes & + \\
\hline & \multirow{8}{*}{ Energy Rating } & $\mathrm{A}$ & dummy & \multirow{8}{*}{$\begin{array}{c}\text { Indicates if the dwelling has } \\
\text { an energy rating: Letters A, B, } \\
\text { C, D, E, F or G, or has no label } \\
\text { (NT). }\end{array}$} & Yes & + \\
\hline & & B & dummy & & Yes & + \\
\hline & & $\mathrm{C}$ & dummy & & Yes & + \\
\hline & & $\mathrm{D}$ & dummy & & Yes & (Ref.) \\
\hline & & E & dummy & & Yes & - \\
\hline & & $\mathrm{F}$ & dummy & & Yes & - \\
\hline & & G & dummy & & Yes & - \\
\hline & & NT & dummy & & Yes & - \\
\hline \multirow{5}{*}{$\begin{array}{l}\text { Building } \\
\text { characteristics } \\
\text { (B) }\end{array}$} & \multirow{5}{*}{ Equipment } & B_elevator & dummy & Availability of elevator (=1). & Yes & + \\
\hline & & B_parking & dummy & $\begin{array}{l}\text { Availability of garage slot } \\
\qquad(=1) .\end{array}$ & Yes & + \\
\hline & & B_storeroom & dummy & $\begin{array}{l}\text { Availability of storage room } \\
(=1) .\end{array}$ & Yes & + \\
\hline & & B_pool & dummy & $\begin{array}{l}\text { Availability of swimming } \\
\text { pool (=1). }\end{array}$ & Yes & + \\
\hline & & B_garden & dummy & Availability of garden $(=1)$ & Yes & + \\
\hline \multirow{14}{*}{$\begin{array}{l}\text { Location } \\
\text { characteristics } \\
\text { (C) }\end{array}$} & \multirow{9}{*}{ Comarca } & C_Alicante & dummy & \multirow{9}{*}{$\begin{array}{c}\text { Identifier of the comarca: } \\
\text { Alicante, Marina Alta, Marina } \\
\text { Baja, Bajo Vinalopó, Bajo } \\
\text { Segura, El Condado, Alcoy, } \\
\text { Alto Vinalopó and Medio } \\
\text { Vinalopó. (Comarcas are } \\
\text { administrative units } \\
\text { equivalent to the districts in } \\
\text { England or the Kreise in } \\
\text { Germany). }\end{array}$} & Reference & \\
\hline & & C_Marina_Alta & dummy & & Yes & + \\
\hline & & C_Marina_Baja & dummy & & Yes & + \\
\hline & & C_Bajo_Vinalopo & dummy & & Yes & - \\
\hline & & C_Bajo_Segura & dummy & & Yes & - \\
\hline & & C_Condado & dummy & & Yes & - \\
\hline & & C_Alcoy & dummy & & Yes & - \\
\hline & & C_Alto_Vinalopo & dummy & & Yes & - \\
\hline & & C_Medio_Vinalopo & $o$ dummy & & Yes & - \\
\hline & \multirow{3}{*}{ Climatic zone } & Zone_B4 & dummy & \multirow{3}{*}{$\begin{array}{l}\text { Identifier of the climatic zone } \\
\text { according to the municipality } \\
\text { in accordance with the } \\
\text { CTE-DB-HE of } 2019 .\end{array}$} & No & \\
\hline & & Zone_C3 & dummy & & No & \\
\hline & & Zone_D3 & dummy & & No & \\
\hline & \multirow{2}{*}{ Location } & C_dist_pharmacy & numerical & $\begin{array}{l}\text { Distance from the dwelling to } \\
\text { the nearest pharmacy, in } \mathrm{km} \text {. }\end{array}$ & Yes & - \\
\hline & & C_dist_health & numerical & $\begin{array}{l}\text { Distance from the dwelling to } \\
\text { the health centre, in } \mathrm{km} \text {. }\end{array}$ & Yes & - \\
\hline
\end{tabular}


Table 1. Cont.

\begin{tabular}{|c|c|c|c|c|c|c|}
\hline Category & Characteristics & Variable & Unit & Description of the Variable & Used & Expected Sign \\
\hline & & C_dist_hospital & numerical & $\begin{array}{l}\text { Distance from the dwelling to } \\
\text { the hospital, in km. }\end{array}$ & Yes & - \\
\hline & & C_dist_educ1 & numerical & $\begin{array}{l}\text { Distance from the dwelling to } \\
\text { level } 1 \text { educational centres } \\
\text { (infant and primary), in } \mathrm{km} \text {. }\end{array}$ & Yes & - \\
\hline & & C_dist_educ2 & numerical & $\begin{array}{l}\text { Distance from the dwelling to } \\
\text { level } 2 \text { educational centres } \\
\text { (secondary and high school), } \\
\text { in km. }\end{array}$ & Yes & - \\
\hline & & C_coastalregion & dummy & $\begin{array}{l}\text { Identification of property } \\
\text { location within a coastal } \\
\text { region. }\end{array}$ & Yes & + \\
\hline & & C_FAR & numerical & $\begin{array}{l}\text { Floor Area Ratio (total } \\
\text { building floor area/gross } \\
\text { sector area), } 150 \mathrm{~m} \text { alrededor } \\
\text { del edificio, in } \mathrm{m}^{2} \text { floor } \\
\text { area } / \mathrm{m}^{2} \text { sector area. }\end{array}$ & Yes & - \\
\hline \multirow{6}{*}{$\begin{array}{l}\text { Neighborhood } \\
\text { characteristics } \\
\text { (D) }\end{array}$} & \multirow{6}{*}{ Neighborhood } & D_dependency & numerical & $\begin{array}{l}\text { Dependency ratio (sum of the } \\
\text { population aged }>64 \text { and } \\
<16 / \text { population aged } 16-64 \text { ). }\end{array}$ & Yes & + \\
\hline & & D_elderly & numerical & $\begin{array}{c}\text { Aging Index (population } \\
\text { aged }>64 / \text { population aged } \\
0-15 \text { ). }\end{array}$ & Yes & + \\
\hline & & D_foreigners & numerical & $\begin{array}{l}\text { Percentage of foreign } \\
\text { population. }\end{array}$ & Yes & + \\
\hline & & D_no_studies & numerical & $\begin{array}{l}\text { Percentage of population } \\
\text { without education. }\end{array}$ & Yes & - \\
\hline & & D_students & numerical & $\begin{array}{l}\text { Percentage of the population } \\
\text { with primary, secondary } \\
\text { studies and high school. }\end{array}$ & No & \\
\hline & & D_university & numerical & $\begin{array}{l}\text { Percentage of the population } \\
\text { with university studies. }\end{array}$ & Yes & + \\
\hline \multirow{10}{*}{$\begin{array}{l}\text { Market } \\
\text { characteristics } \\
\text { (E) }\end{array}$} & Price & Ln_price & numerical & $\begin{array}{l}\text { Dependent variable. The } \\
\text { natural log of the property } \\
\text { price offered by the seller (in } \\
\text { Euro). }\end{array}$ & Yes & \\
\hline & \multirow{3}{*}{ Seller } & E_professional & dummy & \multirow{3}{*}{$\begin{array}{c}\text { Identifier of the seller: } \\
\text { professional, private or bank. }\end{array}$} & Yes & + \\
\hline & & E_private & dummy & & Reference & \\
\hline & & E_bank & dummy & & Yes & - \\
\hline & \multirow{3}{*}{ Occupancy } & E_vacant_dw & numerical & \multirow{3}{*}{$\begin{array}{l}\text { Percentage of vacant } \\
\text { dwellings, main and } \\
\text { secondary. }\end{array}$} & No & \\
\hline & & E_main_dw & numerical & & No & \\
\hline & & E_secondary_dw & numerical & & Yes & + \\
\hline & \multirow{3}{*}{ Housing tenure } & E_rented_dw & numerical & \multirow{3}{*}{$\begin{array}{l}\text { Percentage of dwellings for } \\
\text { rent, mortgaged or owned. }\end{array}$} & Yes & + \\
\hline & & E_mortgaged_dw & numerical & & No & \\
\hline & & E_homeownership & numerical & & No & \\
\hline
\end{tabular}

\subsection{Descriptive Statistics}

The descriptive statistics of the variables are shown in Table 2. 
Table 2. Descriptive statistics for the variables.

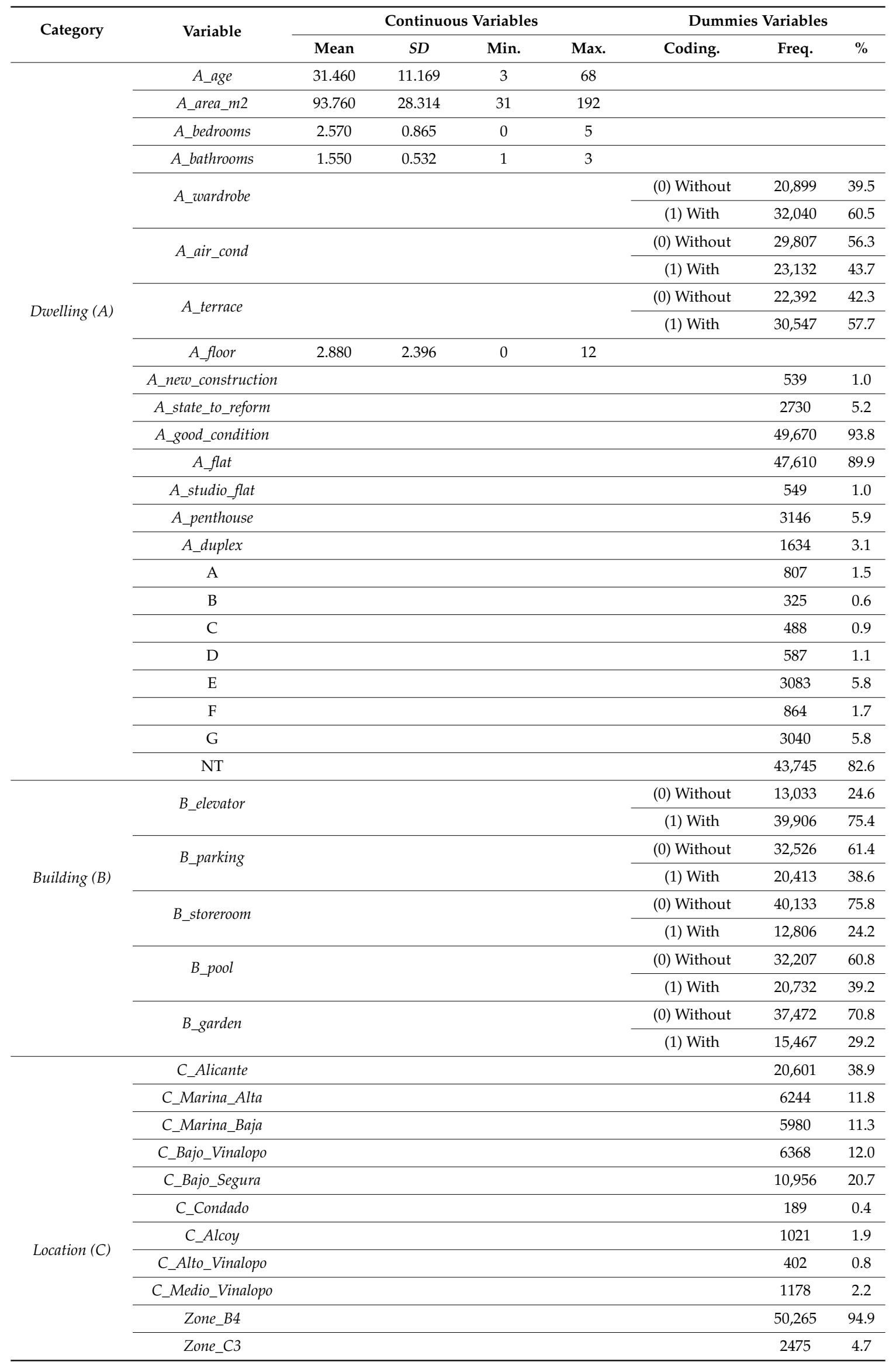


Table 2. Cont.

\begin{tabular}{|c|c|c|c|c|c|c|c|c|}
\hline \multirow{2}{*}{ Category } & \multirow{2}{*}{ Variable } & \multicolumn{4}{|c|}{ Continuous Variables } & \multicolumn{3}{|c|}{ Dummies Variables } \\
\hline & & Mean & $S D$ & Min. & Max. & Coding. & Freq. & $\%$ \\
\hline & Zone_D3 & & & & & & 199 & 0.4 \\
\hline & C_dist_pharmacy & 0.517 & 0.739 & 0 & 9.51 & & & \\
\hline & C_dist_health & 1.211 & 1.396 & 0 & 18.86 & & & \\
\hline & C_dist_hospital & 6.244 & 5.707 & 0.02 & 30.33 & & & \\
\hline & C_dist_educ1 & 0.888 & 1.036 & 0 & 13.32 & & & \\
\hline & C_dist_educ2 & 1.402 & 1.555 & 0.01 & 18.18 & & & \\
\hline & C_coastalregion & & & & & $\begin{array}{c}(0) \\
\text { Non-coastal }\end{array}$ & 19,349 & 36.5 \\
\hline & & & & & & (1) Coastal & 33,590 & 63.5 \\
\hline & C_FAR & 1.155 & 0.861 & 0 & 7.62 & & & \\
\hline \multirow{6}{*}{$\begin{array}{l}\text { Neighborhood } \\
\text { (D) }\end{array}$} & D_dependency & 0.528 & 0.187 & 0 & 1.81 & & & \\
\hline & D_elderly & 1.841 & 1.815 & 0 & 11.56 & & & \\
\hline & D_foreigners & 24.065 & 20.998 & 0 & 92.52 & & & \\
\hline & D_no_studies & 7.232 & 5.202 & 0 & 43.78 & & & \\
\hline & D_students & 60.601 & 9.736 & 0 & 85.51 & & & \\
\hline & D_university & 17.218 & 9.650 & 0 & 54.01 & & & \\
\hline \multirow{10}{*}{ Market (E) } & Ln_price & 11.628 & 0.537 & 10.32 & 12.94 & & & \\
\hline & E_professional & & & & & & 41,533 & 78.5 \\
\hline & E_private & & & & & & 10,272 & 19.4 \\
\hline & E_bank & & & & & & 1134 & 2.1 \\
\hline & E_vacant_dw & 16.189 & 12.802 & 0 & 67.73 & & & \\
\hline & E_main_dw & 57.053 & 26.879 & 9.49 & 100.00 & & & \\
\hline & E_secondary_dw & 26.690 & 24.782 & 0 & 84.18 & & & \\
\hline & E_rented_dw & 13.616 & 10.590 & 0 & 84.62 & & & \\
\hline & E_mortgaged_dw & 38.996 & 16.930 & 3.70 & 96.15 & & & \\
\hline & E_homeownership & 41.616 & 15.536 & 0 & 82.76 & & & \\
\hline
\end{tabular}

\subsection{Methodology}

The analysis of variance allows for the contrasting of the null hypothesis that the means of $K$ populations $(K>2)$ are equal, with the alternative hypothesis that at least one of the populations differs from the others in terms of its expected value (Equation (2)). The one-way analysis of variance consists of three parts. The first part of the analysis permits contrasting of the null hypothesis of equality of means in the groups through the $F$ statistic. The second contrasts the equality of the variances of the dependent variable in the groups using Levene's test. The third and final part of the analysis determines which of the distinct levels of the factor differ from the others, based on different post hoc tests.

$$
\begin{gathered}
\mathrm{H}_{0}: \mu_{1}=\mu_{2}=\ldots=\mu_{K}=\mu \\
\mathrm{H}_{1}: \exists \mu_{j} \neq \mu ; j=1,2, \ldots, K
\end{gathered}
$$

The regression model is estimated using ordinary least squares (OLS), and its specification is semilogarithmic, based on the following expression:

$$
\ln \left(P_{i}\right)=\alpha+\sum_{j=1}^{n} \beta_{j} X_{i j}+\sum_{k=1}^{m} \gamma_{k} D_{i k}+\varepsilon_{i}
$$

where $\ln \left(P_{i}\right)$ is the natural logarithm of the advertised asking price for housing " $i$ "; $\alpha$ is the fixed component, it does not depend on the market; $\beta_{j}$ is the parameter to estimate related to the characteristic 
" $j " ; X_{i j}$ is the continuous variable that collects the characteristic " $j$ " of the observation " $i$ "; $\gamma_{k}$ is the parameter to estimate related to the characteristic " $k$ "; $D_{i k}$ is the dummy variable that collects the characteristic " $k$ " of the observation " $i$ "; and $\varepsilon_{i}$ is the error term in the observation " $i$ ".

The semilogarithmic functional form was selected, since according to [53,54], this form offers certain advantages. First, it facilitates the interpretation of the coefficients. That is, for each increase in unit of the explanatory variable $\left(X_{j}\right.$ and $\left.D_{k}\right)$, the dependent variable $(P)$-in this case, the asking price - varies on average $(100 \cdot \beta)$. And second, it minimizes the problem of heteroscedasticity, improving the goodness of fit of the estimates.

The model is estimated on distinct occasions, based on the energy qualification characteristic (Table 3), such that the results obtained may be compared with other studies. For this analysis, the SPSS statistics package for Windows, version 24 was used [55], based on the method of "excluding cases listwise". This leads to the elimination of observations with missing data.

Table 3. Summary of estimates made based on the reference used, Ref.(qualification letter), and sample size.

\begin{tabular}{ccc}
\hline Estimates & Energy Rating Variables & Final Sample \\
\hline 1 & ABCDEFG/Ref. NT & 52,939 \\
2 & A/Ref. NT & 44,552 \\
3 & A/B/C/D/E/F/G/Ref. NT & 52,939 \\
4 & A/B/C/Ref. D/E/F/G & 9194 \\
5 & ABC/Ref. D/EFG & 9194 \\
6 & AB/C/Ref. D/E/F/G & 9194 \\
7 & A/B/C/D/E/F/Ref. G & 9194 \\
8 & ABC/D/E/F/Ref. G & 9194 \\
9 & AB/C/D/E/F/Ref. G & 9194 \\
\hline
\end{tabular}

\section{Results}

\subsection{One-Way Analysis of Variance (ANOVA)}

In the database created, from a sample of 52,939 homes, only 9194 published their energy qualifications (17.4\%), despite the fact that Royal Decree 235/2013 [15] requires the publication of energy rating of homes that are being sold or rented. This low percentage leads us to believe that the failure to publish an energy qualification may have some sort of advantage for real estate sellers. In order to examine this supposition, a statistical test was created for a one-way analysis of variance (ANOVA), graphically revealing the data in Figure 6. By evaluating the homogeneity of the variance of each group using Levene's test $\left(F_{(7,52931)}=68.8, p=0.000\right)$, the variance of the groups is found to differ. This result supports the use of robust tests of equality of means, specifically, those by Welch [56] $\left(F_{(7,2185)}=314.2, p=0.000\right)$ and Brown-Forsythe $[57]\left(F_{(7,3835)}=237.6 ; p=0.000\right)$, which confirm that the mean asking prices differ between energy qualification letters.

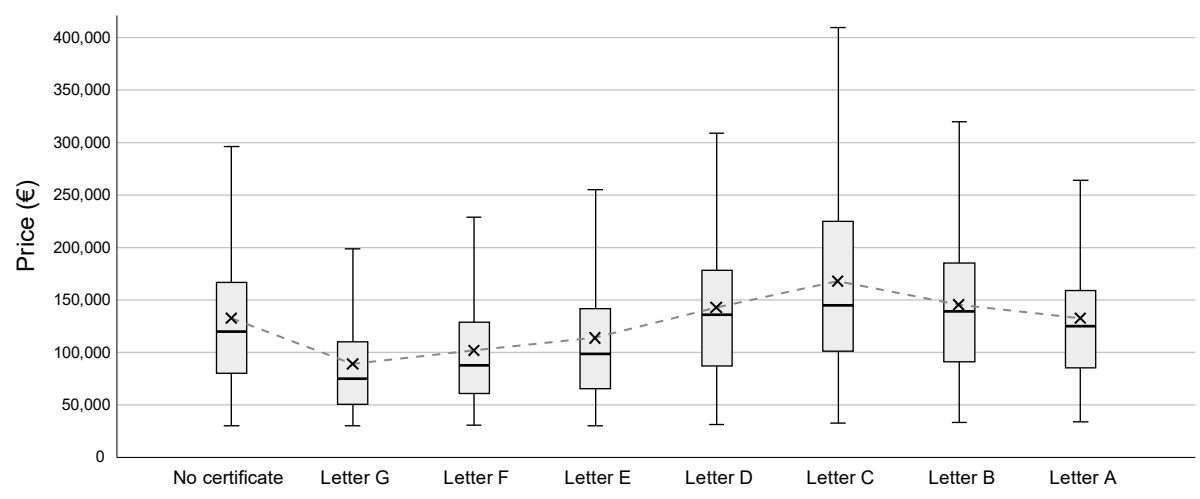

Figure 6. Graph representing the mean asking price and box plot, based on energy qualification. 
To identify the relationships between the groups, a "post hoc" test was performed with Scheffé's method and a classification of the groupings (or homogenous subgroupings) based on the value of the means. For each subset, a test was carried out on the equality of means hypothesis, with significances of over 0.05 (no difference in means), in accordance with that observed in Table 4 . Subset 1 is formed by housing with letters $\mathrm{G}$ and $\mathrm{F}$, whose means do not differ significantly $(p=0.055)$. Subset 2 includes housing with letters $\mathrm{F}$ and $\mathrm{E}$, whose means do not differ significantly $(p=0.123)$. Subset 3 is made up of homes with letters NT, A, D and B, whose means do not differ significantly $(p=0.053)$, and subset 4 consists of only those homes with letter $C$, which, obviously, do not differ from themselves $(p=1.0)$.

Table 4. Homogenous subsets of the mean asking prices by qualification letters.

\begin{tabular}{|c|c|c|c|c|c|}
\hline \multirow{2}{*}{ Energy Rating } & \multirow{2}{*}{$N$} & \multicolumn{4}{|c|}{ Subset for Alpha = 0.05} \\
\hline & & 1 & 2 & 3 & 4 \\
\hline Letter G & 3040 & $89,216.5$ & & & \\
\hline Letter F & 864 & $102,037.9$ & $102,037.9$ & & \\
\hline Letter E & 3083 & & $113,680.5$ & & \\
\hline NT (no label) & 43,745 & & & $132,699.2$ & \\
\hline Letter A & 807 & & & $133,694.0$ & \\
\hline Letter D & 587 & & & $142,756.2$ & \\
\hline Letter B & 325 & & & $145,554.3$ & \\
\hline Letter C & 488 & & & & $168,049.7$ \\
\hline Sig. & & 0.055 & 0.123 & 0.053 & 1.000 \\
\hline
\end{tabular}

\subsection{Regression Analysis}

Upon introducing the variables in the regression model, problems of self-correction were observed between some of the same. Therefore, a total of eight variables have been discarded. Three correspond to the climate area (Zone_B4,ZZone_C3, and Zone_D3), one is referred to the percentage of the population with primary and secondary school educations (D_students), two are referred to the percentages of vacant and main homes (E_vacant_dw and $E \_m a i n \_d w$ ), and two more are referred to the percentages of mortgaged homes and properties with homeowners (E_mortgaged_dw and E_homeownership). Figure A1 in the Appendix A shows a graph with the most relevant correlations.

In order to determine if the estimates achieved suitable quality criteria, the following were examined: the normality of the population, the lack of problems of specification in the estimates (no multicollinearity, heteroscedasticity or autocorrelation), the statistical significance of the estimates, and finally, that the proportion of the estimated variance was high $\left(R^{2}\right)$. The normality of the population is verified through a histogram (Figure 7a,d) and a graph of normality of the residuals (Figure $7 \mathrm{~b}, \mathrm{e}$ ), revealing that the sample has a normal distribution. The multicollinearity was verified via the VIF statistic (Variance Inflation Factor), with various authors suggesting that there are collinearity problems if any VIF exceeds 10 [58,59]. In the new estimations made, the majority of the VIF values are between 1 and 4.6, therefore it is considered that there are no problems arising from multicollinearity. The heteroscedasticity was analyzed with a residual dispersion plot (Figure $7 \mathrm{c}, \mathrm{f}$ ) and there was no evidence of serious problems of heteroscedasticity, given the random distribution of the residuals. The existence of autocorrelation was verified using the Durbin-Watson statistic, obtaining values close to two in all of the estimations, which suggests the absence of autocorrelation in the residuals $[60,61]$. The significance of each estimation is measured with Snedecor's F-test, being found to be statistically significant. The coefficient of determination (adjusted $R^{2}$ ) of the estimates is indicated in Table 5 and all of these have an explanatory power approaching $71 \%$. In summary, the estimations have a sufficient level of robustness and significance, making them acceptable for purposes of inference making. To control the fixed effects due to the spatial location of the data, the comarcas location variables are used. A positive spatial autocorrelation is detected with the Moran's I test [62,63] (residuals from 
estimation $3, I=0.274, z=99.89, p<0.001$; inverse distance squared, bandwidth $500 \mathrm{~m}$ ), a common result in global regression models [64].

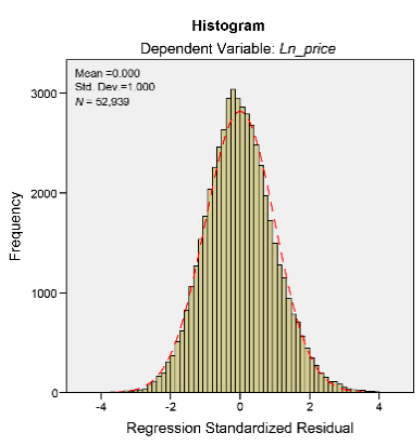

(a)

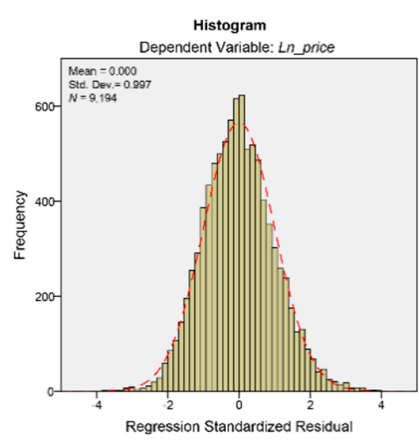

(d)

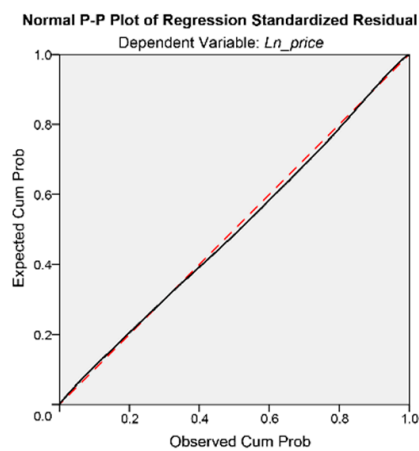

(b)

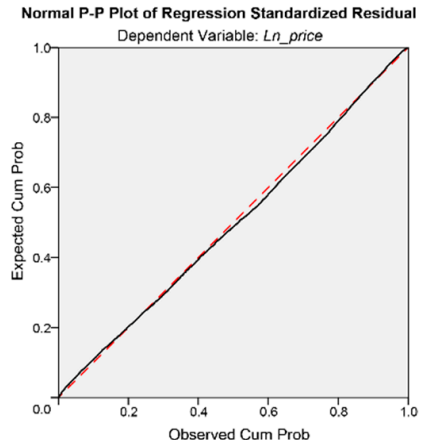

(e)

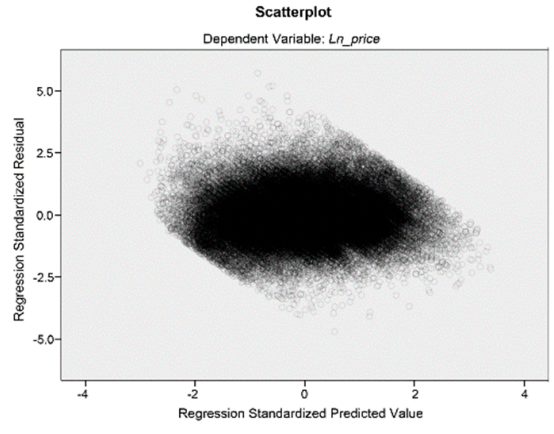

(c)

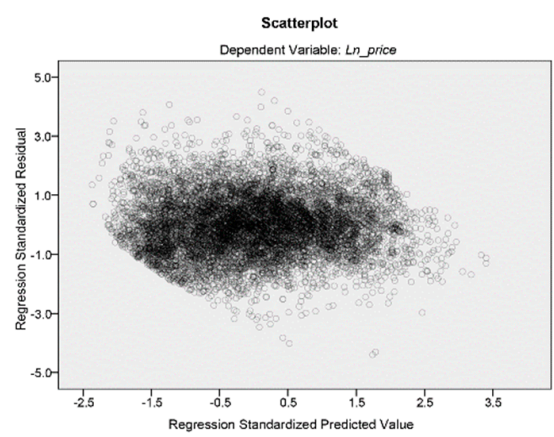

$(\mathbf{f})$

Figure 7. Graphs of the estimation 3: (a) histogram and normal curve of the standardized residual error; (b) P-P plot of residual normality; (c) scatter plot of the predicted values and standardized errors. Graphs of the estimation 4: (d) histogram and normal curve of the standardized residual error; (e) P-P plot of residual normality; (f) scatter plot of the predicted values and standardized errors. 
Table 5. Results of the model estimations according to the energy characteristic.

\begin{tabular}{|c|c|c|c|c|c|c|c|c|c|}
\hline \multirow{3}{*}{ Variable } & \multicolumn{9}{|c|}{ Estimates } \\
\hline & 1 & 2 & 3 & 4 & 5 & 6 & 7 & 8 & 9 \\
\hline & ABCDEFG/Ref.NT & A/Ref.NT & $\mathrm{A} / \mathrm{B} / \mathrm{C} / \mathrm{D} / \mathrm{E} / \mathrm{F} / \mathrm{G} /$ Ref.NT & $\mathrm{A} / \mathrm{B} / \mathrm{C} /$ Ref.D/E/F/G & ABC/Ref.D/EFG & $\mathrm{AB} / \mathrm{C} /$ Ref.D/E/F/G & $\mathrm{A} / \mathrm{B} / \mathrm{C} / \mathrm{D} / \mathrm{E} / \mathrm{F} /$ Ref.G & ABC/D/E/F/Ref.G & $\mathrm{AB} / \mathrm{C} / \mathrm{D} / \mathrm{E} / \mathrm{F} /$ Ref.G \\
\hline \multirow[t]{2}{*}{ Intercept } & $10.099^{* * *}(0.011)$ & $10.082^{* * *}(0.011)$ & $10.102 * * *(0.011)$ & $10.225^{* * *}(0.029)$ & $10.216^{* * *}(0.029)$ & $10.228^{* * *}(0.029)$ & $10.137^{* * *}(0.026)$ & $10.131^{* * *}(0.026)$ & $10.141^{* * *}(0.026)$ \\
\hline & \multicolumn{9}{|c|}{ Dwelling characteristics $(A)$} \\
\hline A_age & $\begin{array}{c}-0.0005^{* * *} \\
(0.0001)\end{array}$ & $0.0001(0.0002)$ & $-0.0005 * * *(0.0001)$ & $-0.0029 * * *(0.0003)$ & $\begin{array}{c}-0.0029 * * * \\
(0.0003)\end{array}$ & $\begin{array}{c}-0.0029 * * * \\
(0.0003)\end{array}$ & $\begin{array}{c}-0.0029 * * * \\
(0.0003)\end{array}$ & $\begin{array}{c}-0.0029 * * * \\
(0.0003)\end{array}$ & $-0.0029^{* * *}(0.0003)$ \\
\hline A_area_m2 & $0.0058^{* * *}(0.0001)$ & $0.0058^{* * *}(0.0001)$ & $0.0058 * * *(0.0001)$ & $0.0058^{* * *}(0.0002)$ & $0.0058^{* * *}(0.0002)$ & $0.0058^{* * *}(0.0002)$ & $0.0058^{* * *}(0.0002)$ & $0.0058^{* * *}(0.0002)$ & $0.0058^{* * *}(0.0002)$ \\
\hline A_bedrooms & $-0.002(0.002)$ & $0.004(0.003)$ & $-0.002(0.002)$ & $-0.021 * * *(0.006)$ & $-0.021^{* * *}(0.006)$ & $-0.021^{* * *}(0.006)$ & $-0.021^{* * *}(0.006)$ & $-0.021^{* * *}(0.006)$ & $-0.021^{* * *}(0.006)$ \\
\hline A_bathrooms & $0.217^{* * *}(0.003)$ & $0.214^{* * *}(0.004)$ & $0.216^{* * *}(0.003)$ & $0.224^{* * *}(0.008)$ & $0.225^{* * *}(0.008)$ & $0.225^{* * *}(0.008)$ & $0.224^{* * *}(0.008)$ & $0.225^{* * *}(0.008)$ & $0.225^{* * *}(0.008)$ \\
\hline A_wardrobe & $0.013^{* * *}(0.003)$ & $0.015^{* * *}(0.003)$ & $0.012 * * *(0.003)$ & $0.002(0.009)$ & $0.003(0.009)$ & $0.002(0.009)$ & $0.002(0.009)$ & $0.002(0.009)$ & $0.002(0.009)$ \\
\hline A_air_cond & $0.077^{* * *}(0.003)$ & $0.074^{* * *}(0.003)$ & $0.076^{* * *}(0.003)$ & $0.084^{* * *}(0.008)$ & $0.086^{* * *}(0.008)$ & $0.084^{* * *}(0.008)$ & $0.084^{* * *}(0.008)$ & $0.086^{* * *}(0.008)$ & $0.084^{* * *}(0.008)$ \\
\hline A_terrace & $0.009 * *(0.003)$ & $0.006 *(0.003)$ & $0.008^{* *}(0.003)$ & $0.028^{* * *}(0.008)$ & $0.029 * * *(0.008)$ & $0.028^{* * *}(0.008)$ & $0.028^{* * *}(0.008)$ & $0.029^{* * *}(0.008)$ & $0.028^{* * *}(0.008)$ \\
\hline A_floor & $0.004^{* * *}(0.001)$ & $0.004^{* * *}(0.001)$ & $0.004^{* * *}(0.001)$ & $0.0002(0.002)$ & $0.0002(0.002)$ & $0.0001(0.002)$ & $0.0002(0.002)$ & $0.0002(0.002)$ & $0.0001(0.002)$ \\
\hline A_new_construction & $0.224^{* * *}(0.013)$ & $0.224^{* * *}(0.014)$ & $0.222 * * *(0.013)$ & $0.208^{* * *}(0.038)$ & $0.191 * * *(0.038)$ & $0.189 * * *(0.038)$ & $0.208^{* * *}(0.038)$ & $0.190 * * *(0.038)$ & $0.189^{* * *}(0.038)$ \\
\hline A_state_to_reform & $-0.151^{* * *}(0.006)$ & $-0.168^{* * *}(0.007)$ & $-0.152^{* * *}(0.006)$ & $-0.095^{* * *}(0.013)$ & $-0.094^{* * *}(0.013)$ & $-0.095^{* * *}(0.013)$ & $-0.095^{* * *}(0.013)$ & $-0.095^{* * *}(0.013)$ & $-0.095^{* * *}(0.013)$ \\
\hline \multicolumn{10}{|l|}{$\begin{array}{l}\text { A_good_condition } \\
\text { (Ref.) }\end{array}$} \\
\hline \multicolumn{10}{|l|}{ A_flat (Ref.) } \\
\hline A_studio_flat & $-0.223^{* * *}(0.013)$ & $-0.214^{* * *}(0.014)$ & $-0.223^{* * *}(0.013)$ & $-0.236^{* * *}(0.033)$ & $-0.235^{* * *}(0.033)$ & $-0.233^{* * *}(0.033)$ & $-0.236^{* * *}(0.033)$ & $-0.236 * * *(0.033)$ & $-0.233^{* * *}(0.033)$ \\
\hline A_penthouse & $0.108^{* * *}(0.006)$ & $0.112 * * *(0.006)$ & $0.108^{* * *}(0.006)$ & $0.095^{* * *}(0.016)$ & $0.091^{* * *}(0.016)$ & $0.094^{* * *}(0.016)$ & $0.095^{* * *}(0.016)$ & $0.091^{* * *}(0.016)$ & $0.094^{* * *}(0.016)$ \\
\hline A_duplex & $0.044^{* * *}(0.008)$ & $0.049^{* * *}(0.008)$ & $0.044^{* * *}(0.008)$ & $0.013(0.021)$ & $0.010(0.021)$ & $0.012(0.021)$ & $0.013(0.021)$ & $0.010(0.021)$ & $0.012(0.021)$ \\
\hline ABCDEFG & $-0.032 * * *(0.004)$ & & & & & & & & \\
\hline $\mathrm{ABC}$ & & & & & $-0.025(0.015)$ & & & $0.062 * * *(0.011)$ & \\
\hline $\mathrm{AB}$ & & & & & & $-0.046 * *(0.016)$ & & & $0.041^{* *}(0.013)$ \\
\hline $\mathrm{A}$ & & $-0.003(0.010)$ & $-0.002(0.010)$ & $-0.026(0.017)$ & & & $0.061^{* * *}(0.014)$ & & \\
\hline B & & & $-0.080^{* * *}(0.016)$ & $-0.091 * * *(0.021)$ & & & $-0.003(0.019)$ & & \\
\hline C & & & $0.049 * * *(0.013)$ & $0.014(0.019)$ & & $0.015(0.019)$ & $0.101^{* * *}(0.016)$ & & $0.102 * * *(0.016)$ \\
\hline $\mathrm{D}$ & & & $0.033^{* *}(0.012)$ & Ref. & Ref. & Ref. & $0.087^{* * *}(0.014)$ & $0.088^{* * *}(0.014)$ & $0.087^{* * *}(0.014)$ \\
\hline E & & & $-0.043^{* * *}(0.006)$ & $-0.081^{* * *}(0.014)$ & & $-0.081^{* * *}(0.014)$ & $0.006(0.008)$ & $0.006(0.008)$ & $0.006(0.008)$ \\
\hline $\mathrm{F}$ & & & $-0.038^{* * *}(0.010)$ & $-0.080^{* * *}(0.016)$ & & $-0.079 * * *(0.016)$ & $0.008(0.012)$ & $0.007(0.012)$ & $0.008(0.012)$ \\
\hline G & & & $-0.053^{* * *}(0.006)$ & $-0.087^{* * *}(0.014)$ & & $-0.087^{* * *}(0.014)$ & Ref. & Ref. & Ref. \\
\hline EFG & & & & & $-0.083^{* * *}(0.013)$ & & & & \\
\hline
\end{tabular}


Table 5. Cont.

\begin{tabular}{|c|c|c|c|c|c|c|c|c|c|}
\hline \multirow{3}{*}{ Variable } & \multicolumn{9}{|c|}{ Estimates } \\
\hline & 1 & 2 & 3 & 4 & 5 & 6 & 7 & 8 & 9 \\
\hline & ABCDEFG/Ref.NT & A/Ref.NT & $\mathrm{A} / \mathrm{B} / \mathrm{C} / \mathrm{D} / \mathrm{E} / \mathrm{F} / \mathrm{G} /$ Ref.NT & A/B/C/Ref.D/E/F/G & ABC/Ref.D/EFG & $\mathrm{AB} / \mathrm{C} /$ Ref.D/E/F/G & A/B/C/D/E/F/Ref.G & ABC/D/E/F/Ref.G & $\mathrm{AB} / \mathrm{C} / \mathrm{D} / \mathrm{E} / \mathrm{F} /$ Ref.G \\
\hline \multirow[t]{2}{*}{ NT (no label) } & Ref. & Ref. & Ref. & & & & & & \\
\hline & \multicolumn{9}{|c|}{ Building characteristics (B) } \\
\hline B_elevator & $0.185^{* * *}(0.003)$ & $0.179^{* * *}(0.004)$ & $0.183^{* * *}(0.003)$ & $0.195^{* * *}(0.008)$ & $0.196^{* * *}(0.008)$ & $0.195^{* * *}(0.008)$ & $0.195^{* * *}(0.008)$ & $0.195^{* * *}(0.008)$ & $0.195^{* * *}(0.008)$ \\
\hline B_parking & $0.111^{* * *}(0.003)$ & $0.111^{* * *}(0.003)$ & $0.110^{* * *}(0.003)$ & $0.102 * * *(0.009)$ & $0.102 * * *(0.009)$ & $0.101^{* * *}(0.009)$ & $0.102 * * *(0.009)$ & $0.102^{* * *}(0.009)$ & $0.101^{* * *}(0.009)$ \\
\hline B_storeroom & $0.048^{* * *}(0.003)$ & $0.048^{* * *}(0.003)$ & $0.047^{* * *}(0.003)$ & $0.049^{* * *}(0.009)$ & $0.048^{* * *}(0.010)$ & $0.049^{* * *}(0.010)$ & $0.049 * * *(0.009)$ & $0.048^{* * *}(0.010)$ & $0.049^{* * *}(0.010)$ \\
\hline B_pool & $0.092 * * *(0.004)$ & $0.093^{* * *}(0.004)$ & $0.092 * * *(0.004)$ & $0.094^{* * *}(0.011)$ & $0.093 * * *(0.011)$ & $0.093^{* * *}(0.011)$ & $0.094^{* * *}(0.011)$ & $0.092 * * *(0.011)$ & $0.093^{* * *}(0.011)$ \\
\hline \multirow[t]{2}{*}{ B_garden } & $0.034^{* * *}(0.004)$ & $0.037^{* * *}(0.004)$ & $0.034^{* * *}(0.004)$ & $-0.002(0.011)$ & $-0.002(0.011)$ & $-0.002(0.011)$ & $-0.002(0.011)$ & $-0.002(0.011)$ & $-0.002(0.011)$ \\
\hline & \multicolumn{9}{|c|}{ Location characteristics (C) } \\
\hline \multicolumn{10}{|l|}{ C_Alicante (Ref.) } \\
\hline C_Marina_Alta & $0.004(0.005)$ & $0.031^{* * *}(0.006)$ & $0.006(0.005)$ & $-0.097^{* * *}(0.013)$ & $-0.099^{* * *}(0.013)$ & $-0.097^{* * *}(0.013)$ & $-0.097^{* * *}(0.013)$ & $-0.099^{* * *}(0.013)$ & $-0.097^{* * *}(0.013)$ \\
\hline C_Marina_Baja & $0.098^{* * *}(0.005)$ & $0.115^{* * *}(0.006)$ & $0.098^{* * *}(0.005)$ & $0.018(0.014)$ & $0.014(0.014)$ & $0.016(0.014)$ & $0.018(0.014)$ & $0.014(0.014)$ & $0.016(0.014)$ \\
\hline C_Bajo_Vinalopo & $0.016^{* *}(0.005)$ & $0.020^{* * *}(0.005)$ & $0.015^{* *}(0.005)$ & $-0.004(0.013)$ & $-0.005(0.013)$ & $-0.003(0.013)$ & $-0.004(0.013)$ & $-0.004(0.013)$ & $-0.003(0.013)$ \\
\hline C_Bajo_Segura & $-0.207^{* * *}(0.005)$ & $-0.211^{* * *}(0.006)$ & $-0.206^{* * *}(0.005)$ & $-0.194^{* * *}(0.012)$ & $-0.194^{* * *}(0.012)$ & $-0.194^{* * *}(0.012)$ & $-0.194^{* * *}(0.012)$ & $-0.194 * * *(0.012)$ & $-0.194^{* * *}(0.012)$ \\
\hline C_Condado & $-0.164^{* * *}(0.021)$ & $-0.164^{* * *}(0.023)$ & $-0.164^{* * *}(0.021)$ & $-0.186^{* * *}(0.056)$ & $-0.192 * * *(0.056)$ & $-0.188^{* * *}(0.056)$ & $-0.186^{* * *}(0.056)$ & $-0.192 * * *(0.056)$ & $-0.188^{* * *}(0.056)$ \\
\hline C_Alcoy & $-0.210^{* * *}(0.010)$ & $-0.214^{* * *}(0.011)$ & $-0.211^{* * *}(0.010)$ & $-0.193^{* * *}(0.022)$ & $-0.192 * * *(0.022)$ & $-0.191^{* * *}(0.022)$ & $-0.193 * * *(0.022)$ & $-0.192 * * *(0.022)$ & $-0.191^{* * *}(0.022)$ \\
\hline C_Alto_Vinalopo & $-0.135^{* * *}(0.016)$ & $-0.116^{* * *}(0.019)$ & $-0.134^{* * *}(0.016)$ & $-0.155^{* * *}(0.028)$ & $-0.156^{* * *}(0.028)$ & $-0.156^{* * *}(0.028)$ & $-0.155^{* * *}(0.028)$ & $-0.156^{* * *}(0.028)$ & $-0.156^{* * *}(0.028)$ \\
\hline C_Medio_Vinalopo & $-0.185^{* * *}(0.009)$ & $-0.186^{* * *}(0.010)$ & $-0.186^{* * *}(0.009)$ & $-0.196^{* * *}(0.020)$ & $-0.196^{* * *}(0.020)$ & $-0.196^{* * *}(0.020)$ & $-0.196^{* * *}(0.020)$ & $-0.196^{* * *}(0.020)$ & $-0.196^{* * *}(0.020)$ \\
\hline C_dist_pharmacy & $-0.017^{* * *}(0.003)$ & $-0.021^{* * *}(0.003)$ & $-0.017^{* * *}(0.003)$ & $-0.005(0.007)$ & $-0.004(0.007)$ & $-0.005(0.007)$ & $-0.005(0.007)$ & $-0.004(0.007)$ & $-0.005(0.007)$ \\
\hline C_dist_health & $0.008^{* * *}(0.001)$ & $0.007^{* * *}(0.001)$ & $0.008^{* * *}(0.001)$ & $0.017^{* * *}(0.003)$ & $0.016^{* * *}(0.003)$ & $0.017^{* * *}(0.003)$ & $0.017^{* * *}(0.003)$ & $0.016^{* * *}(0.003)$ & $0.017^{* * *}(0.003)$ \\
\hline C_dist_hospital & $0.002 * * *(0.000)$ & $0.002^{* * *}(0.000)$ & $0.002 * * *(0.000)$ & $0.003^{* * *}(0.001)$ & $0.003^{* * *}(0.001)$ & $0.003^{* * *}(0.001)$ & $0.003^{* * *}(0.001)$ & $0.003^{* * *}(0.001)$ & $0.003^{* * *}(0.001)$ \\
\hline C_dist_educ1 & $0.027^{* * *}(0.002)$ & $0.026^{* * *}(0.003)$ & $0.026^{* * *}(0.002)$ & $0.021^{* * *}(0.006)$ & $0.021^{* * *}(0.006)$ & $0.021^{* * *}(0.006)$ & $0.021^{* * *}(0.006)$ & $0.021^{* * *}(0.006)$ & $0.021^{* * *}(0.006)$ \\
\hline C_dist_educ2 & $-0.021^{* * *}(0.001)$ & $-0.022 * * *(0.001)$ & $-0.021^{* * *}(0.001)$ & $-0.012^{* * *}(0.003)$ & $-0.012 * * *(0.003)$ & $-0.012 * * *(0.003)$ & $-0.012 * * *(0.003)$ & $-0.012 * * *(0.003)$ & $-0.012^{* * *}(0.003)$ \\
\hline C_coastalregion & $0.146^{* * *}(0.004)$ & $0.140^{* * *}(0.004)$ & $0.145^{* * *}(0.004)$ & $0.166^{* * *}(0.009)$ & $0.165^{* * *}(0.009)$ & $0.165^{* * *}(0.009)$ & $0.166^{* * *}(0.009)$ & $0.165^{* * *}(0.009)$ & $0.165^{* * *}(0.009)$ \\
\hline \multirow[t]{2}{*}{ C_FAR } & $-0.026^{* * *}(0.002)$ & $-0.027^{* * *}(0.002)$ & $-0.027^{* * *}(0.002)$ & $-0.018^{* * *}(0.005)$ & $-0.017^{* *}(0.005)$ & $-0.018^{* * *}(0.005)$ & $-0.018^{* * *}(0.005)$ & $-0.017^{* * *}(0.005)$ & $-0.018^{* * *}(0.005)$ \\
\hline & \multicolumn{9}{|c|}{ Neighborhood characteristics (D) } \\
\hline D_dependency & $0.221^{* * *}(0.008)$ & $0.237^{* * *}(0.009)$ & $0.220^{* * *}(0.008)$ & $0.157^{* * *}(0.021)$ & $0.161^{* * *}(0.021)$ & $0.159^{* * *}(0.021)$ & $0.157^{* * *}(0.021)$ & $0.161^{* * *}(0.021)$ & $0.159^{* * *}(0.021)$ \\
\hline D_elderly & $0.009^{* * *}(0.001)$ & $0.008^{* * *}(0.001)$ & $0.009^{* * *}(0.001)$ & $0.011^{* * *}(0.002)$ & $0.010^{* * *}(0.002)$ & $0.011^{* * *}(0.002)$ & $0.011^{* * *}(0.002)$ & $0.011^{* * *}(0.002)$ & $0.011^{* * *}(0.002)$ \\
\hline$D_{\text {foreigners }}$ & $0.001 * * *(0.000)$ & $0.001^{* * *}(0.000)$ & $0.001^{* * *}(0.000)$ & $0.001^{* * *}(0.000)$ & $0.001^{* * *}(0.000)$ & $0.001^{* * *}(0.000)$ & $0.001^{* * *}(0.000)$ & $0.001^{* * *}(0.000)$ & $0.001^{* * *}(0.000)$ \\
\hline D_no_studies & $-0.008^{* * *}(0.000)$ & $-0.008^{* * *}(0.000)$ & $-0.008^{* * *}(0.000)$ & $-0.005^{* * *}(0.001)$ & $-0.005^{* * *}(0.001)$ & $-0.005^{* * *}(0.001)$ & $-0.005^{* * *}(0.001)$ & $-0.005^{* * *}(0.001)$ & $-0.005^{* * *}(0.001)$ \\
\hline D_university & $0.009^{* * *}(0.000)$ & $0.009^{* * *}(0.000)$ & $0.009^{* * *}(0.000)$ & $0.008^{* * *}(0.000)$ & $0.009^{* * *}(0.000)$ & $0.009^{* * *}(0.000)$ & $0.008^{* * *}(0.000)$ & $0.009^{* * *}(0.000)$ & $0.009^{* * *}(0.000)$ \\
\hline
\end{tabular}


Table 5. Cont.

\begin{tabular}{|c|c|c|c|c|c|c|c|c|c|}
\hline \multirow{3}{*}{ Variable } & \multicolumn{9}{|c|}{ Estimates } \\
\hline & 1 & 2 & 3 & 4 & 5 & 6 & 7 & 8 & 9 \\
\hline & ABCDEFG/Ref.NT & A/Ref.NT & A/B/C/D/E/F/G/Ref.NT & A/B/C/Ref.D/E/F/G & ABC/Ref.D/EFG & $\mathrm{AB} / \mathrm{C} /$ Ref.D/E/F/G & $\mathrm{A} / \mathrm{B} / \mathrm{C} / \mathrm{D} / \mathrm{E} / \mathrm{F} /$ Ref.G & $\mathrm{ABC} / \mathrm{D} / \mathrm{E} / \mathrm{F} /$ Ref.G & $\mathrm{AB} / \mathrm{C} / \mathrm{D} / \mathrm{E} / \mathrm{F} /$ Ref.G \\
\hline & \multicolumn{9}{|c|}{ Market characteristics (E) } \\
\hline E_professional & $-0.028^{* * *}(0.003)$ & $-0.028^{* * *}(0.004)$ & $-0.025^{* * *}(0.003)$ & $-0.006(0.010)$ & $-0.002(0.009)$ & $-0.010(0.010)$ & $-0.006(0.010)$ & $-0.002(0.009)$ & $-0.010(0.010)$ \\
\hline \multicolumn{10}{|l|}{ E_private(Ref.) } \\
\hline E_bank & $-0.003(0.010)$ & $-0.103^{* * *}(0.029)$ & $0.005(0.010)$ & $-0.006(0.015)$ & $-0.0004(0.014)$ & $-0.010(0.015)$ & $-0.006(0.015)$ & $-0.002(0.015)$ & $-0.010(0.015)$ \\
\hline E_secondary_dw & $0.003^{* * *}(0.000)$ & $0.003 * * *(0.000)$ & $0,0033^{* * *}(0.000)$ & $0.002^{* * *}(0.000)$ & $0.002 * * *(0.000)$ & $0.002 * * *(0.000)$ & $0.002^{* * *}(0.000)$ & $0.002 * * *(0.000)$ & $0.002 * * *(0.000)$ \\
\hline E_rented_dw & $0.003^{* * *}(0.000)$ & $0.002^{* * *}(0.000)$ & $0.003^{* * *}(0.000)$ & $0.003^{* * *}(0.000)$ & $0.003^{* * *}(0.000)$ & $0.003^{* * *}(0.000)$ & $0.003^{* * *}(0.000)$ & $0.003^{* * *}(0.000)$ & $0.003^{* * *}(0.000)$ \\
\hline$N$ & 52,939 & 44,552 & 52,939 & 9194 & 9194 & 9194 & 9194 & 9194 & 9194 \\
\hline$R^{2}$ & 0.708 & 0.702 & 0.708 & 0.716 & 0.716 & 0.716 & 0.716 & 0.716 & 0.716 \\
\hline adj. $R^{2}$ & 0.708 & 0.702 & 0.708 & 0.715 & 0.714 & 0.715 & 0.715 & 0.714 & 0.715 \\
\hline Std. Error & 0.29 & 0.29 & 0.29 & 0.30 & 0.30 & 0.30 & 0.30 & 0.30 & 0.30 \\
\hline$F$ (sig.) & $2979 * * *$ & $2442 * * *$ & $2621^{* * *}$ & $481^{* * *}$ & $523 * * *$ & $490 * * *$ & $481^{* * *}$ & $500 * * *$ & $490^{* * *}$ \\
\hline Durbin-Watson & 1.89 & 1.91 & 1.89 & 1.79 & 1.79 & 1.79 & 1.79 & 1.79 & 1.79 \\
\hline
\end{tabular}

Notes: dependent variable Ln_price; signification: ${ }^{* * *} p<0.001,{ }^{* *} p<0.01,{ }^{*} p<0.05$; standard errors in parentheses. 
Currently, studies carried out have been based on distinct scenarios and the literature has revealed a certain diversity in terms of determining the letter (or set of letters) of reference for measuring and comparing the impact of energy qualifications on housing prices (Figure 8). This circumstance hinders comparisons between the premium resulting from going from one value to another within the ABCDEFG qualification scale. To facilitate comparison between studies, some authors have recommended that letters not be grouped and that $\mathrm{D}$ be considered the letter of reference $[32,65]$, since it is in the middle of the scale.

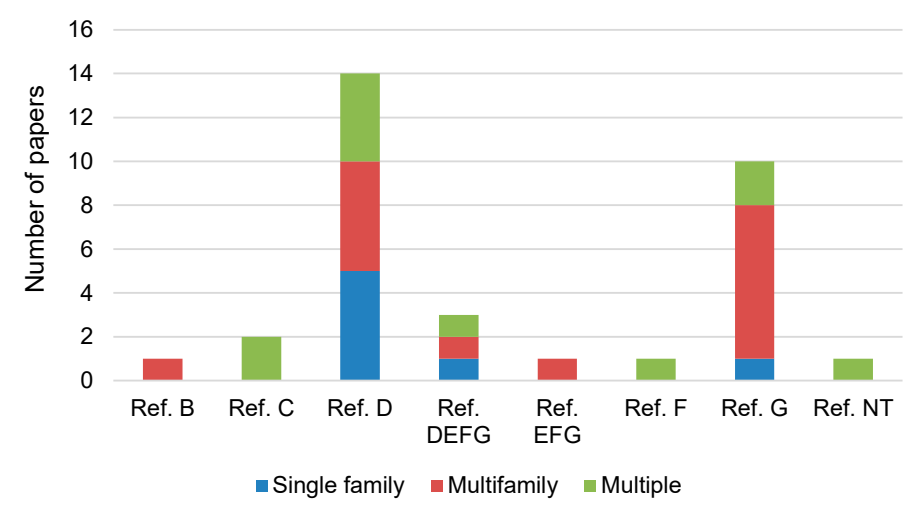

Figure 8. Letters of reference used to estimate the price premium (graph elaborated from 20 papers).

Based on this background, the results of the model obtained for the estimate 4 are presented, since it is the one that complies with the recommendations of using letter $\mathrm{D}$ as a reference. As for the characteristics of the housing, the model estimates that for each additional year (in terms of age of the housing), the asking price will be reduced a mean of $0.29 \%$. As for size, the estimated impact implies that an increase of one square meter in surface area results in a $0.58 \%$ price increase, whereas the addition of another bedroom leads to a reduction of $2.09 \%$. However, an additional bathroom represents a mean price increase of $22.44 \%$. If the property has extras, such as built-in wardrobe, air conditioning or a terrace, the mean impact on prices estimated by the model is $0.25 \%, 8.42 \%$ and $2.81 \%$, respectively. The results reveal that a home situated on an additional story has a price increase of $0.02 \%$. Using as a reference a second-hand home in good state, the model estimates a mean discount in the asking price of $9.49 \%$ for a second-hand home that needs renovation. On the other hand, if the home is a new construction, the results reveal a price increase of $20.78 \%$. Within the typology of homes and using apartments as the reference, a duplex or attic apartment has a price increase of $1.30 \%$ and $9.45 \%$, respectively, whereas studio apartments have a discount of $23.56 \%$.

The values obtained in the estimation of the parameters related to the building characteristics, such as having an elevator, garage, storage space or swimming pool, imply a mean price increase of $19.48 \%, 10.18 \%, 4.88 \%$ and $9.38 \%$, respectively. On the other hand, having a garden has a contrary effect, leading to a mean price reduction of $0.16 \%$ (not significant).

As for characteristics related to location, for properties situated in neighborhoods with a higher gross development (those in which there are more homes per sector surface area), the model estimates a mean reduction in price of approximately $1.80 \%$. As for the geographic distances, they are all statistically significant, except for the distance to pharmacies. The results reveal that for each kilometer that the housing is distanced from pharmacies or level 2 schools (secondary and high schools), the price decreases by $0.50 \%$ and $1.18 \%$. The opposite occurs when the housing is distanced from health centers, hospitals and level 1 schools (infant and primary schools). Homes that are in coastal towns have a price increase of $16.57 \%$. Finally, the estimated impact on prices of homes situated in the Marina Baja district have an increase of $1.81 \%$ with regard to the reference district (Alicante). As for the rest of the districts, the effect that is estimated by the model implies a reduction in asking prices, reaching discounts of between $15 \%$ and $20 \%$ in interior and southern districts of the province [66,67]. 
As for the neighborhood characteristics, an increase of $1 \%$ was found for dependency and ageing, implying an increase in sales price of $0.16 \%$ and $0.01 \%$, respectively. As for the percentage of foreigners or the percentage of individuals with university studies, an increase of $1 \%$ for these variables implies a $0.12 \%$ and $0.85 \%$ price increase, respectively. On the other hand, with a $1 \%$ increase in the percentage of the population without an education, there is a price reduction of $0.54 \%$.

As for market characteristics, the model estimations reveal increases in prices in areas having a higher percentage of homes in rent and secondary homes, at $0.32 \%$ and $0.21 \%$, respectively. The sale of homes indicates that when the properties are sold by professionals or banks, the price is reduced by a mean of $0.63 \%$ and $0.62 \%$, respectively, with these values not being statistically significant.

As for the characteristics having a greater impact on asking prices, the five variables from the estimates having the greatest explanatory power, according to the standardized beta coefficients (not included due to problems of extension) are: (A) housing characteristics-constructed surface area and number of bathrooms; (B) building characteristics-having an elevator; and (C) location characteristics-percentage of individuals with university studies and being situated in a coastal town.

As for the energy qualification, the results for the entire sample are summarized in Figure 9, where it is observed that the housing with any qualification type (ABCDEFG grouping) and homes with high energy qualifications (letter A) had lower prices, respectively, $3.22 \%$ and $0.30 \%$ lower. Estimate 3 reveals that housing with high qualifications (letters $A$ and B) do not have better economic premiums than other homes with lower qualifications or those that have not published their qualifications. This suggests that by not publishing the energy qualification, sellers may ask for higher prices than those asked for other homes with lower qualifications (E, F or G).

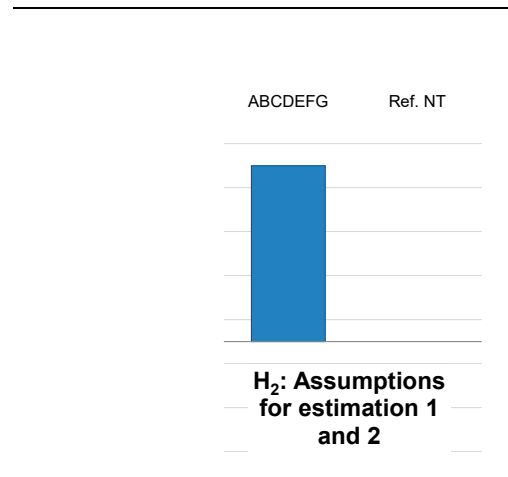

(a)

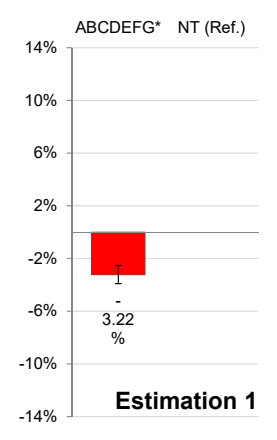

(b)

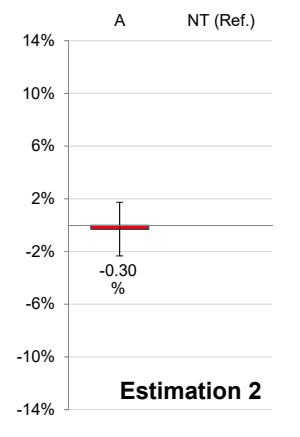

(c)

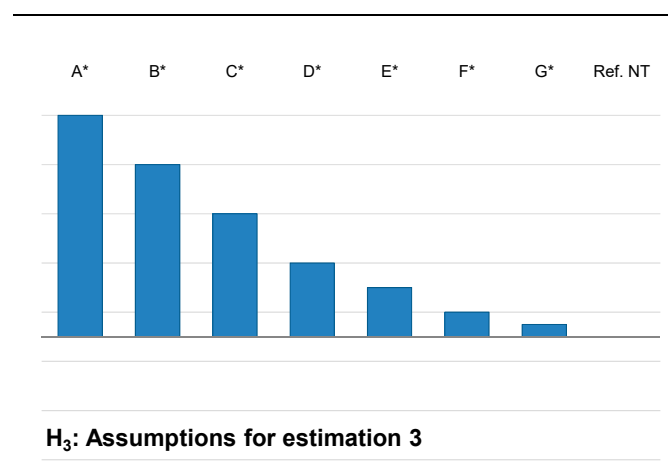

(d)

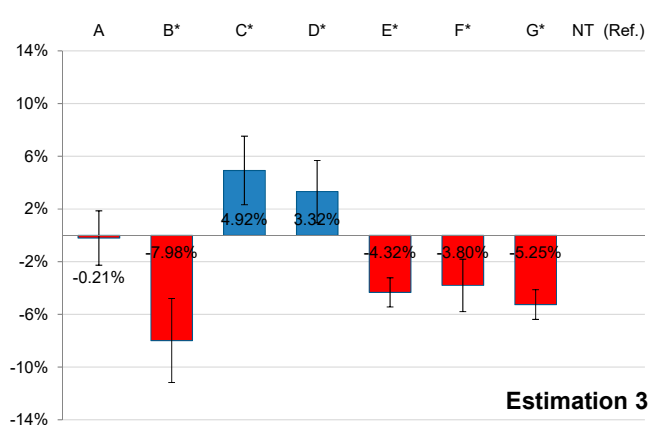

(e)

Figure 9. Bar graph with the asking price premiums (\%) and CI (95\%) for estimations 1 to 3 of the model. (a) Assumptions for estimations 1 and 2; (b) estimation 1; (c) estimation 2; (d) Assumptions for estimation 3 ; (e) estimation 3 . Note: ${ }^{*}$ statistically significant result. 
Estimations 3 to 9 are carried out with the sample of homes that published their energy qualifications (Figures 9 and 10). If letter $\mathrm{D}$ is used as the reference (estimations 4, 5 and 6), it is observed that letters $\mathrm{A}, \mathrm{B}$ (and the $\mathrm{AB}$ grouping) do not have better premiums than those of letters $\mathrm{C}$ and $\mathrm{D}$. In the case of homes qualified as E, F or G, they have very similar negative premiums, a decrease of approximately $8 \%$. If adopting the letter $G$ as a reference (estimations 7,8 and 9), the positive price premiums for letters $C$ and $\mathrm{D}$ are of special note, as well as the similarity of prices for the lower qualifications (E, F and $G$ ).

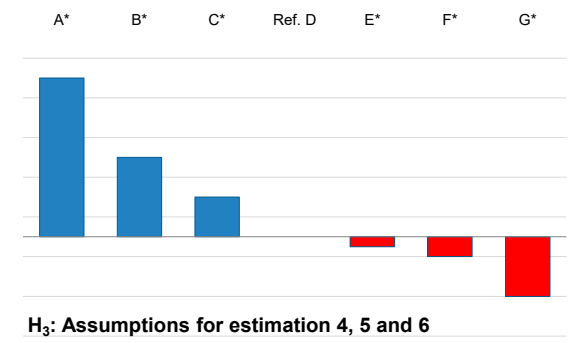

(a)

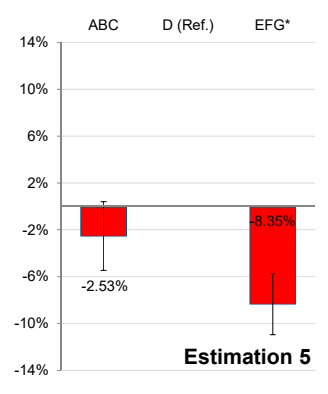

(c)

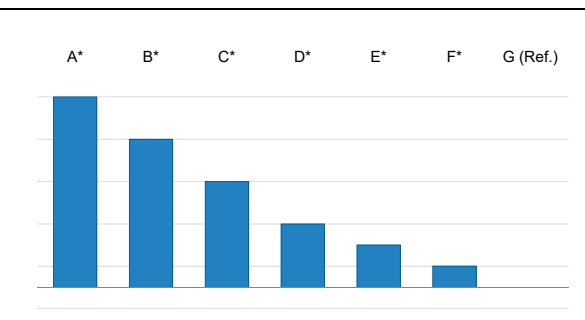

$H_{3}$ : Assumptions for estimation 7, 8 and 9

(e)

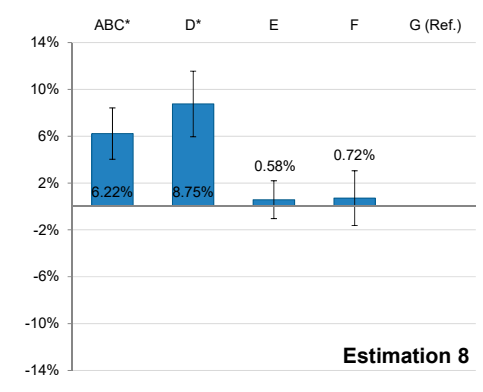

(g)

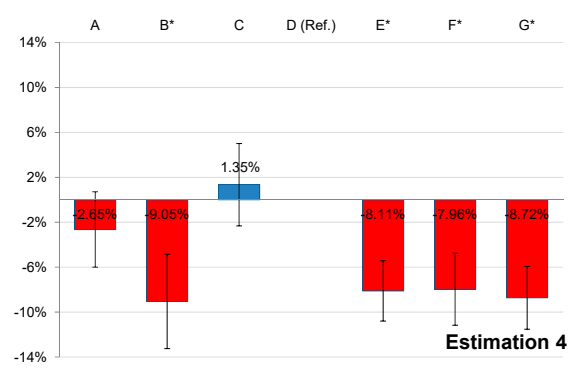

(b)

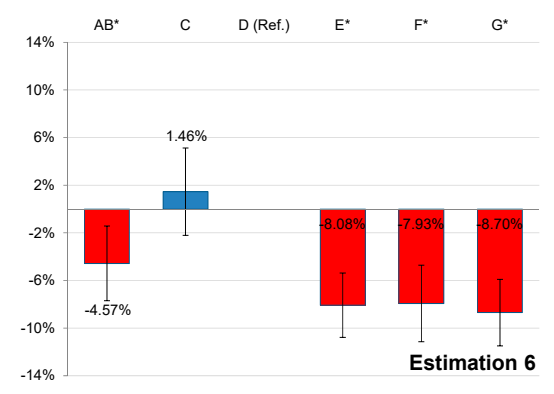

(d)

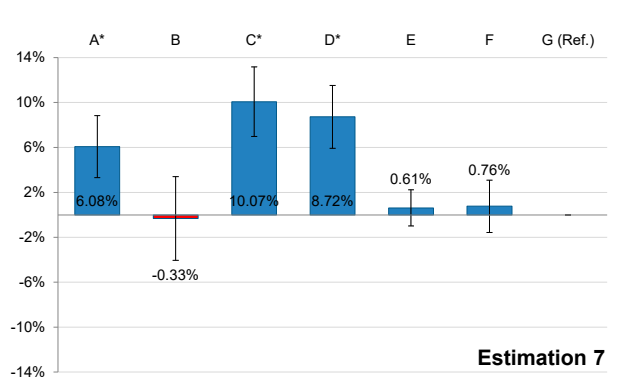

(f)

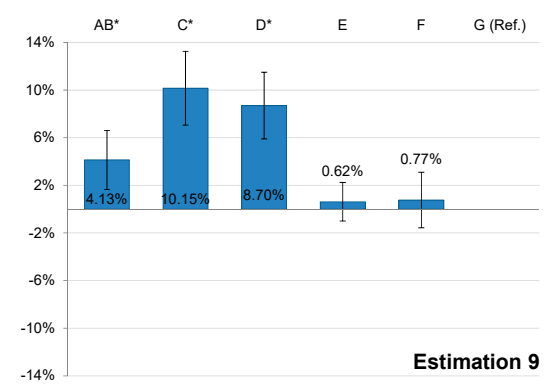

(h)

Figure 10. Bar graphs with asking price premiums (\%) and CI (95\%) for estimations 4 to 9 of the 
model. (a) Assumptions for estimations 4, 5 and 6; (b) estimation 4; (c) estimation 5; (d) estimation 6; (e) Assumptions for estimates 7, 8 and 9; (f) estimation 7; (g) estimation 8; (h) estimation 9. Note: * statistically significant result.

\section{Discussion}

The results of the one-way analysis of variance (ANOVA) support the first hypothesis $\left(\mathrm{H}_{1}\right)$, since it reveals that the mean of the asking prices for the properties that do not publish their energy qualification (NT) are similar to those of homes with higher ratings, letters A, B or D (subset 3). Therefore, the sellers of these properties have no interest in publishing the qualification letter. These results are in line with other works [16,31]. It is very likely that homes hiding the energy qualification have letters E, F or G, since this segment represents $86 \%$ of the labelled building stock of the autonomous community [68].

The results of the regression model obtained from estimations 1,2 and 3 are contradictory to the second hypothesis $\left(\mathrm{H}_{2}\right)$ proposed in this document. Homes with an energy qualification-ABCDEFG grouping (estimation 1) —or a high qualification-letter A (estimation 2) - have a discount in price of $3.22 \%$ or $0.30 \%$, respectively, with respect to the homes that do not publish their energy qualification (NT). In addition, if comparing estimations 1 and 2 with the results obtained by Cespedes-Lopez, et al. [32], it is observed that having an energy qualification, as compared to not having one, does not have a positive effect on the asking price, as it does in Europe, in general $(2.32 \%)$. In estimation 3 , it is observed that homes that do not publish their energy qualifications have higher prices than those qualified with letters B, E, F and G. This estimation may be compared with [22] (see Table 6), where a positive impact was found on prices for the high qualifications (A and $\mathrm{B}$ ), and a decrease of between 0.8 and $1.6 \%$ for the poorer qualified (D, E, F and G).

Table 6. Comparative of premiums in \% from this study (estimations 4 to 9) with studies published in Europe on energy qualifications.

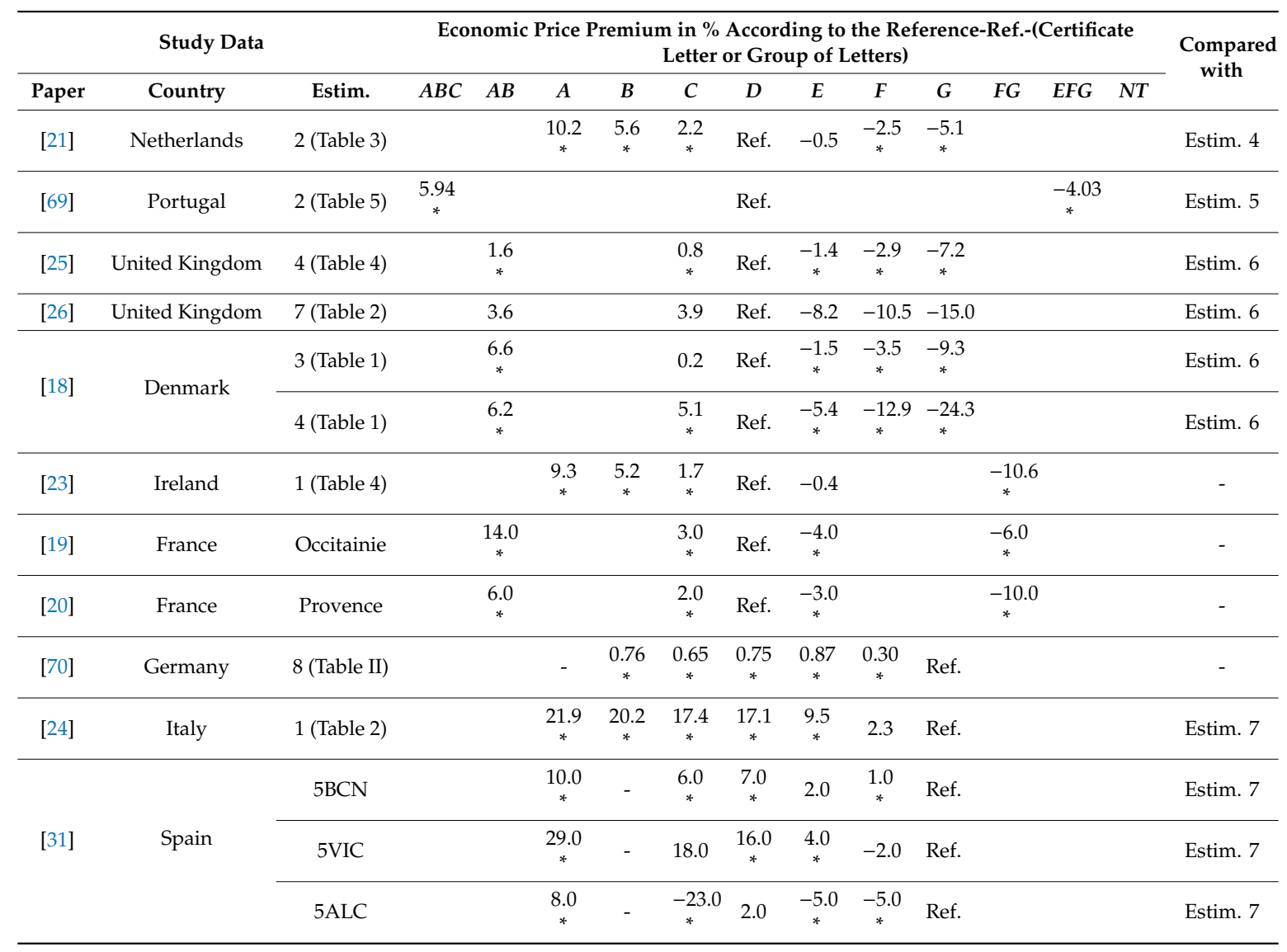


Table 6. Cont.

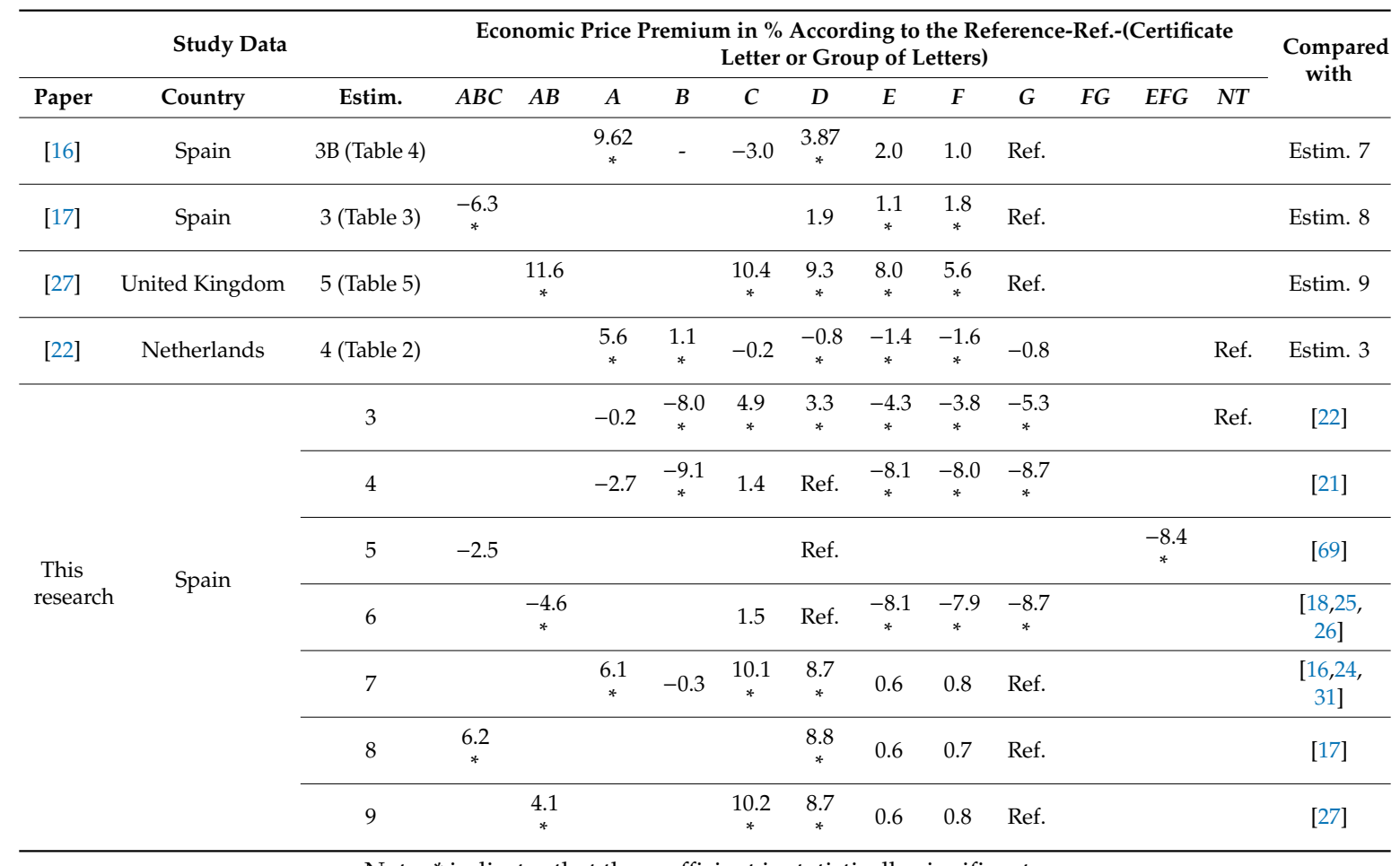

Note: * indicates that the coefficient is statistically significant.

Results of the regression model for estimations 4 to 9 (Figure 10) are contrary to the third hypothesis $\left(\mathrm{H}_{3}\right)$. For estimations 4, 5 and 6 (ref. D) a negative sign was anticipated for letters below the reference letter, and a positive impact for letters above the reference letters (Figure 10a). Estimations 7, 8 and 9 (ref. G) anticipated that the premium of letter A would be positive and the sign of the subsequent letters would also be positive and with a decreasing impact on the prices until reaching the reference letter (Figure 10e). However, upon comparing the expected and obtained results, it can be seen that they do not comply with the initially proposed hypothesis $\left(\mathrm{H}_{3}\right)$, since homes with better qualifications do not have better premiums than those with poorer qualifications. For housing with high qualifications-letters A, B and the AB and ABC groupings-a discount was obtained with respect to the reference housing -letter D- (estimations 4, 5 and 6). For estimations 7, 8 and 9, it is seen that housing qualified as $C$ and $D$ are the best valued of the market segment, with the highest premiums as compared to the reference $\mathrm{G}$.

If comparing these results with those obtained from other studies (Table 6), it may be observed that, in general, housing with higher qualifications have higher sales prices. For example, estimation 6 from this study may be compared to the results of $[18,25,26]$, where high qualifications (the AB grouping) obtained a positive price premium, and for the housing with low qualifications, the premiums are negative and decrease as the qualification decreases.

\section{Conclusions}

This work seeks to examine the effect of energy qualifications on the asking price of housing located in the Alicante (Spain) real estate market. To do so, a database was constructed based on 52,939 observations, of which 9194 offered information on energy qualifications (17.4\%). The information contained in the database has permitted the creation of 63 variables that are used to estimate the regression model. In order to compare the results of this work with those of other studies, the model has been estimated 9 times.

The first objective attempts to determine if an interest exists in not publishing energy qualification information for homes being sold. Two initial hypotheses are proposed $-\mathrm{H}_{1}$ and $\mathrm{H}_{2}$. The one-way analysis of variance (ANOVA) reveals that the $\mathrm{H}_{1}$ hypothesis is supported, since hiding the qualification may lead to higher asking prices. The second proposed hypothesis- $\mathrm{H}_{2}$-attempts to contrast whether or not energy qualification is a determining characteristic of the asking price. Estimations 1 and 2 reveal that this hypothesis is rejected, since homes with an energy qualification-ABCDEFG grouping—or those having a high qualification—letter A—as 
compared to those that did not publish their rating - NT—, have a negative premium of $3.2 \%$ (significant) and of $0.3 \%$ (not sig.) respectively.

The second objective proposes quantifying the economic impact of energy qualification on the asking price, offering the hypothesis- $\mathrm{H}_{3}$. Estimations 4 to 9 suggest the contrary, finding that housing qualified with letters $\mathrm{C}$ and D have higher premiums than housing with higher qualifications (A or B).

This study reveals that, in multi-family housing sold in the Alicante (Spain) province, a positive relationship does not exist between the energy certification system and the housing's asking price. This is due to a variety of reasons.

- $\quad$ First, real estate sellers and owners who do not publish energy qualifications offer their homes at prices that are similar to those having high qualifications.

- Second, there is the lack of sanctions placed by the public administration on companies, owners and real estate portals that do not publish the energy qualifications of the housing that is for sale or rent, motivating owners to not publish the letter and generating distorted asking prices for the housing. Therefore, it is important for the administration to closely supervise compliance with regulations and assign the necessary resources to local authorities to ensure said compliance, and if needed, to impose sanctions.

- Third, owners are not interested in improving energy qualifications, since, according to [71,72] there is no compensation for the additional investment needed to improve this qualification. And fourth and finally, the current regulations for housing only require that these homes obtain energy qualification if they are going to sell, rent or publish. However, there is no obligation to obtain a minimum qualification, so the improved energy performance of the homes is not encouraged $[73,74]$.

- $\quad$ Fifth and finally, society's perception of EPC is negative, as revealed by several studies relying on surveys completed by professional real estate agents [74,75] or energy certifiers [73]. Regardless, these studies suggest that the main criteria used to select a home is price and location [74-76].

Currently, both nationally and regionally, economic incentives exist in order to offer value to housing with higher qualifications and to promote renovation. On a national level, the PAREER II (2014-2020) [77] program was financed with 204 million euros. Regionally speaking (Valencian community), there are distinct plans such as RENHATA [78], which intends to offer 4.95 million euros between 2020-2021 to improve the preservation of housing, accessibility and energy rehabilitation. Given that in Spain, there are over 9.5 million buildings, it is unlikely that a country's building stock will be renewed thanks to public budgets. Therefore, it will be necessary to rely on private initiatives, based on market incentives (higher sales prices, higher rents) that encourage investments in energy renewal of buildings. In this way, not only would property owners directly benefit from these renewals, the entire population would also receive benefits. This would ensure a more sustainable and environmentally respectful building stock, helping to create cleaner cities and an improved quality of life.

Author Contributions: Conceptualization, M.-F.C.-L. and R.-T.M.-G.; methodology, M.-F.C.-L., R.-T.M.-G., V.R.P.-S. and P.M.-C.; formal analysis, investigation, data curation, and writing - original draft preparation, M.-F.C.-L., R.-T.M.-G. and V.R.P.-S.; writing-review and editing, M.-F.C.-L., R.-T.M.-G., V.R.P.-S. and P.M.-C. All authors have read and agreed to the published version of the manuscript.

Funding: This research and the ACP were partially funded by Universidad de Alicante (http://dx.doi.org/10. 13039/100009092).

Acknowledgments: To the Spanish General Council of Technical Architecture (http://www.arquitectura-tecnica. com) for the granting of a subsidy to promote the doctorate training in the course year 2018/19, granted to the author, M.-F.C.-L. The contents of this publication are the exclusive responsibility of the authors and do not necessarily reflect the opinion of the Universidad de Alicante or the Spanish General Council of Technical Architecture.

Conflicts of Interest: The authors declare no conflict of interest. 


\section{Appendix A}

Table A1. Principales indicadores del sector inmobiliario para España y la provincia de Alicante.

\begin{tabular}{|c|c|c|c|c|}
\hline Block & Indicator & España & Alicante & Source \\
\hline \multirow{3}{*}{$\begin{array}{l}\text { Use of the housing } \\
\qquad(2011)\end{array}$} & Main housing & $18,083,692(71.7 \%)$ & $738,367(58.0 \%)$ & \multirow{3}{*}{ [36] } \\
\hline & Secondary housing & $3,681,565(14.6 \%)$ & $326,705(25.6 \%)$ & \\
\hline & Empty housing & $3,443,365(13.7 \%)$ & $209,024(16.4 \%)$ & \\
\hline \multirow{2}{*}{$\begin{array}{c}\text { Tenancy regime } \\
\text { (2011) }\end{array}$} & Ownership & $14,274,987(85.4 \%)$ & $613,626(88.6 \%)$ & \multirow{2}{*}{ [36] } \\
\hline & Rental & $2,438,574(14.6 \%)$ & $79,165(11.4 \%)$ & \\
\hline \multirow{3}{*}{$\begin{array}{l}\text { Housing real estate } \\
\text { transactions (2019) }\end{array}$} & Total number of transactions & 569,993 & 42,418 & \multirow{3}{*}{ [34] } \\
\hline & $\begin{array}{l}\text { Residents in Spain } \\
\quad \text { (Spaniards) }\end{array}$ & $474,102(83.2 \%)$ & $21,815(51.4 \%)$ & \\
\hline & $\begin{array}{l}\text { Residents in Spain } \\
\text { (foreigners) }\end{array}$ & $91,668(16.1 \%)$ & $19,447(45.8 \%)$ & \\
\hline \multirow{2}{*}{$\begin{array}{l}\text { Type of building } \\
\text { (2019) }\end{array}$} & Single-family home & $5,945,000(32.1 \%)$ & $299,487(22.9 \%)$ & \multirow{2}{*}{ [36] } \\
\hline & Collective housing & $12,591,200(67.9 \%)$ & $1,006,882(77.1 \%)$ & \\
\hline \multirow{4}{*}{$\begin{array}{l}\text { Availability of } \\
\text { heating (2011) }\end{array}$} & Collective or central & $10.56 \%$ & $5.26 \%$ & \multirow{4}{*}{ [36] } \\
\hline & Individual & $46.30 \%$ & $24.87 \%$ & \\
\hline & $\begin{array}{l}\text { Without installation, but } \\
\text { with some device permitting } \\
\text { heating of a room }\end{array}$ & $29.48 \%$ & $54.83 \%$ & \\
\hline & Without heating & $13.66 \%$ & $15.04 \%$ & \\
\hline
\end{tabular}

Table A2. Variables used by other authors for the determination of the price of housing. Own elaboration from [66].

\begin{tabular}{|c|c|c|}
\hline Category & Characteristics & References \\
\hline \multirow{9}{*}{$\begin{array}{c}\text { Dwelling } \\
\text { characteristics }(A)\end{array}$} & Dwelling typology & {$[17,21,23,26,44,79-88]$} \\
\hline & Age of the dwelling & {$[17,26,45,46,79,82-112]$} \\
\hline & Dwelling surface area & $\begin{array}{c}{[16,17,21,28,44-46,80,82-88,90-93,95-101} \\
103-108,110,112-124]\end{array}$ \\
\hline & Number of bedrooms & $\begin{array}{c}{[17,21,23,26,28,45,80,81,84,85,87,88,93,96,103,} \\
113,116,125,126]\end{array}$ \\
\hline & Number of bathrooms & {$[16,17,24,81,84,87,93,100,113,115,121]$} \\
\hline & Floor of the dwelling & {$[16,17,28,44,85,91,99-101,104,110,113,121,124]$} \\
\hline & Terrace & {$[45,87,93,113,118]$} \\
\hline & Wardrobe & {$[105,123]$} \\
\hline & State of conservation & {$[21,45,46,82,86-88,96,123]$} \\
\hline \multirow{3}{*}{$\begin{array}{l}\text { Features of the building } \\
\text { (B) }\end{array}$} & Garage slot & $\begin{array}{c}{[24,45,80,82,83,87,93,100,106-108,113,115} \\
120-123]\end{array}$ \\
\hline & Elevator & {$[16,80,82,86,87,92,93,105,118,123]$} \\
\hline & Swimming pool in the building & {$[16,80,83,86,93,112,113,120,122-124]$} \\
\hline $\begin{array}{l}\text { Characteristics of the } \\
\text { location (C) }\end{array}$ & Location within the territory or the city & $\begin{array}{c}{[17,24,28,80,82,93,97,98,100,101,103,106-108,} \\
111-114,120,122,125,127]\end{array}$ \\
\hline
\end{tabular}


Table A2. Cont.

\begin{tabular}{ccc}
\hline Category & Characteristics & References \\
\hline \multirow{2}{*}{$\begin{array}{c}\text { Characteristics of the } \\
\text { neighbourhood }(D)\end{array}$} & Age of the population & {$[44,45]$} \\
\cline { 2 - 3 } & Number of Foreigners & {$[44,45,47,86,87,104,117]$} \\
\cline { 2 - 3 } & Level of studies & {$[16,44,47,85,89,116,128]$} \\
\hline \multirow{2}{*}{$\begin{array}{c}\text { Market, occupation and } \\
\text { sale characteristics }(E)\end{array}$} & Price & In all studies this is the dependent variable \\
\cline { 2 - 3 } & Use of the dwelling & {$[17,28,96,118]$} \\
\hline
\end{tabular}

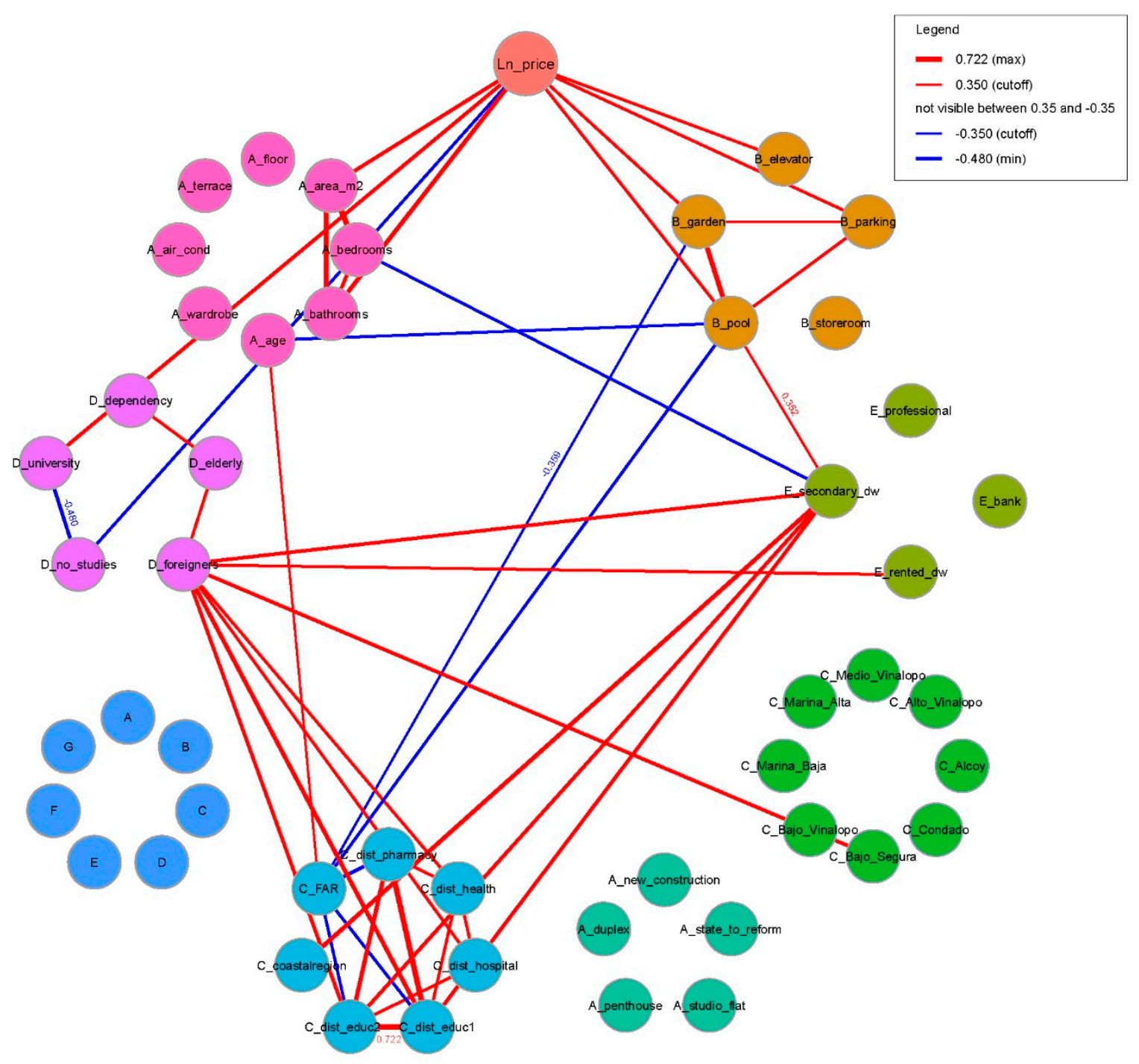

Figure A1. Correlation between the characteristics of the properties—independent variables—and the asking prices. Only correlations greater than 0.35 (in absolute value) are shown.

\section{References}

1. Hirsch, J.; Lafuente, J.J.; Spanner, M.; Geiger, P.; Haran, M.; McGreal, S.; Davis, P.T.; Recourt, R.; de la Paz, P.T.; Perez-Sanchez, V.R.; et al. Stranding Risk E Carbon. Science-Based Decarbonising of the EU Commercial Real Estate Sector; CRREM Report No.1; IIÖ Institut für Immobilienökonomie GmbH: Wörgl, Austria, 2019; p. 143. Available online: https://www.crrem.eu/wp-content/uploads/2019/09/CRREM-Stranding-Risk-CarbonScience-based-decarbonising-of-the-EU-commercial-real-estate-sector.pdf (accessed on 3 September 2019). 
2. The European Parliament and the Council of the European Union. Directive 2002/91/EC of the European Parliament and of the Council of 16 December 2002 on the energy performance of buildings. Off. J. Eur. Communities 2003, 46, 7.

3. The European Parliament and the Council of the European Union. Directive 2010/31/EU of the European Parliament and of the Council of 19 May 2010 on the energy performance of buildings. Off. J. Eur. Communities 2010, 53, 23.

4. The European Parliament and the Council of the European Union. Directive 2012/27/EU of the European Parliament and of the Council of 25 October 2012 on energy efficiency, amending Directives 2009/125/EC and 2010/30/EU and repealing Directives 2004/8/EC and 2006/32/EC. Off. J. Eur. Union 2012, 55, 56.

5. The European Parliament and the Council of the European Union. Directive (EU) 2018/844 of the European Parliament and of the Council of 30 May 2018 amending Directive 2010/31/EU on the energy performance of buildings and Directive 2012/27/EU on energy efficiency. Off. J. Eur. Union 2018, 61, 17.

6. Mudgal, S.; Lyons, L.; Cohen, F.; Lyons, R.C.; Fedrigo-Fazio, D. Energy Performance Certificates in Buildings and Their Impact on Transaction Prices and Rents in Selected EU Countries; Bio Intelligence Service: Paris, France, 2013; p. 158. Available online: https://ec.europa.eu/energy/sites/ener/files/documents/20130619-energy_ performance_certificates_in_buildings.pdf (accessed on 5 January 2018).

7. European Commission. A Programme to Deliver Energy Certificates for Display in Public Buildings across Europe within a Harmonising Framework (EPLABEL). Available online: https://ec.europa.eu/energy/ intelligent/projects/en/projects/eplabel (accessed on 9 October 2019).

8. European Commission. Applying the EPBD to Improve the ENergy PErformance Requirements to EXISTing Buildings (ENPER EXIST). Available online: https://ec.europa.eu/energy/intelligent/projects/en/projects/ enper-exist (accessed on 9 October 2019).

9. European Commission. Social Housing Action to Reduce Energy Consumption (SHARE). Available online: https:/ec.europa.eu/energy/intelligent/projects/en/projects/share (accessed on 9 October 2019).

10. European Commission. Assessment and Improvement of the EPBD Impact (for New Buildings and Building Renovation) (ASIEPI). Available online: https://ec.europa.eu/energy/intelligent/projects/en/projects/asiepi (accessed on 9 October 2019).

11. European Commission. Incentives through Transparency: European Rental Housing Framework for Profitability Calculation of Energetic Retrofitting Investments (RentalCal). Available online: https://cordis. europa.eu/project/id/649656 (accessed on 9 October 2019).

12. European Commission. RESPOND: Integrated Demand REsponse Solution towards Energy POsitive NeighbourhooDs. Available online: https://cordis.europa.eu/project/id/768619 (accessed on 9 October 2019).

13. European Commission. Carbon Risk Real Estate Monitor-Framework for Science Based Decarbonisation Pathways, Toolkit to Identify Stranded Assets and Push Sustainable Investments (CRREM). Available online: https://cordis.europa.eu/project/id/785058 (accessed on 9 October 2019).

14. Ministerio de la Presidencia. Real Decreto 47/2007, de 19 de enero, por el que se aprueba el Procedimiento básico para la certificación de eficiencia energética de edificios de nueva construcción. Bol. Estado Madr. 2007, 27, 4499-4507.

15. Ministerio de la Presidencia. Real Decreto 235/2013, de 5 de abril, por el que se aprueba el procedimiento básico para la certificación de la eficiencia energética de los edificios. Bol. Estado Madr. 2013, 89, 27548-27562.

16. Marmolejo-Duarte, $C$. The incidence of the energy rating on residential values: An analysis for the multifamily market in Barcelona. Inf. Constr. 2016, 68, e156. [CrossRef]

17. Taltavull-de-la-Paz, P.; Perez-Sanchez, V.R.; Mora-Garcia, R.T.; Perez-Sanchez, J.C. Green Premium Evidence from Climatic Areas: A Case in Southern Europe, Alicante (Spain). Sustainability 2019, 11, 686. [CrossRef]

18. Jensen, O.M.; Hansen, A.R.; Kragh, J. Market response to the public display of energy performance rating at property sales. Energy Policy 2016, 93, 229-235. [CrossRef]

19. Notaries-France. La Valeur Verte des Logements en 2016; Étude Statistiques Immobilières: France Métropolitaine, France, 2017; p. 4. Available online: https://immobilier.statistiques.notaires.fr/sites/default/contrib/valeur\% 20_verte.pdf (accessed on 14 March 2019).

20. Notaries-France. La Valeur Verte des Logements en 2017; Étude Statistiques Immobilières: France Métropolitaine, France, 2018; p. 11. Available online: https://www.notaires.fr/sites/default/files/Valeur\%20verte\%20\%20Octobre\%202018.pdf (accessed on 14 March 2019). 
21. Brounen, D.; Kok, N. On the economics of energy labels in the housing market. J. Environ. Econ. Manag. 2011, 62, 166-179. [CrossRef]

22. Chegut, A.; Eichholtz, P.; Holtermans, R. Energy efficiency and economic value in affordable housing. Energy Policy 2016, 97, 39-49. [CrossRef]

23. Hyland, M.; Lyons, R.C.; Lyons, S. The value of domestic building energy efficiency: Evidence from Ireland. Energy Econ. 2013, 40, 943-952. [CrossRef]

24. Bonifaci, P.; Copiello, S. Price premium for buildings energy efficiency: Empirical findings from a hedonic model. Valori Valutazioni 2015, 14, 5-15.

25. Fuerst, F.; McAllister, P.; Nanda, A.; Wyatt, P. Does energy efficiency matter to home-buyers? An investigation of EPC ratings and transaction prices in England. Energy Econ. 2015, 48, 145-156. [CrossRef]

26. Fuerst, F.; McAllister, P.; Nanda, A.; Wyatt, P. Energy performance ratings and house prices in Wales: An empirical study. Energy Policy 2016, 92, 20-33. [CrossRef]

27. Fuerst, F.; McAllister, P.; Nanda, A.; Wyatt, P. An Investigation of the Effect of EPC Ratings on House Prices; 13D/148; Department of Energy \& Climate Change: London, UK, 2013; p. 41. Available online: https://www. gov.uk/government/publications/an-investigation-of-the-effect-of-epc-ratings-on-house-prices (accessed on 30 November 2019).

28. De Ayala, A.; Galarraga, I.; Spadaro, J.V. The price of energy efficiency in the Spanish housing market. Energy Policy 2016, 94, 16-24. [CrossRef]

29. Stanley, S.; Lyons, R.C.; Lyons, S. The price effect of building energy ratings in the Dublin residential market. Energy Effic. 2016, 9, 875-885. [CrossRef]

30. Olaussen, J.O.; Oust, A.; Solstad, J.T. Energy performance certificates-Informing the informed or the indifferent? Energy Policy 2017, 111, 246-254. [CrossRef]

31. Marmolejo-Duarte, C.; Chen, A. The impact of EPC rankings on the Spanish residential market: An analysis for Barcelona, Valence and Alicante. Ciudad Territ. Estud. Territ. 2019, 51, 101-118.

32. Cespedes-Lopez, M.F.; Mora-Garcia, R.T.; Perez-Sanchez, V.R.; Perez-Sanchez, J.C. Meta-Analysis of Price Premiums in Housing with Energy Performance Certificates (EPC). Sustainability 2019, 11, 6303. [CrossRef]

33. Banco de España. El mercado de la vivienda en España entre 2014 y 2019. Doc. Ocas. 2020, 2013, 55.

34. MITMA, Ministerio de Transportes, Movilidad y Agenda Urbana. Transacciones Inmobiliarias (Compraventa). Available online: https://apps.fomento.gob.es/BoletinOnline2/?nivel=2\&orden=34000000 (accessed on 20 February 2020).

35. Ministerio de Vivienda. Real Decreto 314/2006, de 17 de marzo, por el que se aprueba el Código Técnico de la Edificación. Bol. Estado Madr. 2006, 74, 11816-11831.

36. INE, Instituto Nacional de Estadística. Censo de Población y Vivienda de. 2011. Available online: https://www.ine.es/censos2011_datos/cen11_datos_resultados.htm (accessed on 10 October 2019).

37. Lancaster, K.J. A new approach to consumer theory. J. Polit. Econ. 1966, 74, 132-157. [CrossRef]

38. Ridker, R.G.; Henning, J.A. The determinants of residential property values with special reference to air pollution. Rev. Econ. Stat. 1967, 49, 246-257. [CrossRef]

39. Zietz, J.; Zietz, E.N.; Sirmans, G.S. Determinants of house prices: A quantile regression approach. J. Real Estate Financ. Econ. 2008, 37, 317-333. [CrossRef]

40. Sirmans, G.S.; Macpherson, D.A.; Zietz, E.N. The composition of hedonic pricing models. J. Real Estate Lit. 2005, 13, 3-43.

41. MITMA, Ministerio de Transportes, Movilidad y Agenda Urbana. Vivienda Libre. Series Anuales. 3.1. Número de Viviendas Libres Iniciadas. Available online: https://apps.fomento.gob.es/BoletinOnline2/?nivel= 2\&orden $=32000000$ (accessed on 21 October 2019).

42. Hair, J.F.; Black, W.C.; Babin, B.J.; Anderson, R.E. Multivariate Data Analysis, 7th ed.; Pearson Education Limited: Harlow, UK, 2014.

43. Johnson, R.R.; Kuby, P.J. Elementary Statistics, 11th ed.; Cengage Learning: Boston, MA, USA, 2011.

44. Chasco-Yrigoyen, C.; Sánchez-Reyes, B. Externalidades ambientales y precio de la vivienda en Madrid: Un análisis con regresión cuantílica espacial. Rev. Galega Econ. 2012, 21,1-21.

45. Brandt, S.; Maennig, W. The impact of rail access on condominium prices in Hamburg. Transportation 2012, 39, 997-1017. [CrossRef] 
46. Bauer, T.K.; Feuerschütte, S.; Kiefer, M.; an de Meulen, P.; Micheli, M.; Schmidt, T.; Wilke, L.-H. Ein hedonischer Immobilienpreisindex auf Basis von Internetdaten: 2007-2011. AStA Wirtsch. Soz. Arch. 2013, 7, 5-30. [CrossRef]

47. Agnew, K.; Lyons, R.C. The impact of employment on housing prices: Detailed evidence from FDI in Ireland. Reg. Sci. Urban Econ. 2018, 70, 174-189. [CrossRef]

48. Limsombunchai, V.; Gan, C.; Lee, M. House price prediction: Hedonic price model vs. Artificial neural network. Am. J. Appl. Sci. 2004, 1, 193-201. [CrossRef]

49. Lyons, R.C. Can list prices accurately capture housing price trends? Insights from extreme markets conditions. Financ. Res. Lett. 2019, 30, 228-232. [CrossRef]

50. SEC, Sede Electrónica del Catastro Inmobiliario. Información Alfanumérica y Cartografía Vectorial. Available online: https://www.sedecatastro.gob.es/ (accessed on 1 October 2019).

51. Mora-Garcia, R.T. Modelo Explicativo de las Variables Intervinientes en la Calidad del Entorno Construido de las Ciudades. Ph.D. Thesis, Universidad de Alicante, San Vicente del Raspeig, Spain, 2016. Available online: http://hdl.handle.net/10045/65829 (accessed on 15 February 2018).

52. Ministerio de Fomento. Real Decreto 732/2019, de 20 de diciembre, por el que se modifica el Código Técnico de la Edificación, aprobado por el Real Decreto 314/2006, de 17 de marzo. Bol. Estado Madr. 2019, 311, 140488-140674.

53. Kain, J.F.; Quigley, J.M. Housing Markets and Racial Discrimination: A Microeconomic Analysis; National Bureau of Economic Research: New York, NY, USA, 1975; p. 393.

54. Malpezzi, S. Hedonic Pricing Models: A Selective and Applied Review. In Housing Economics and Public Policy; O'Sullivan, T., Gibb, K., Eds.; Blackwell Science: Great Britain, UK, 2003. [CrossRef]

55. IBM Corporation. IBM SPSS Statistics for Windows; IBM Corporation: Armonk, NY, USA, 2016.

56. Welch, B.L. On the Comparison of Several Mean Values: An Alternative Approach. Biometrika 1951, 38, 330-336. [CrossRef]

57. Brown, M.B.; Forsythe, A.B. The Small Sample Behavior of Some Statistics Which Test the Equality of Several Means. Technometrics 1974, 16, 129-132. [CrossRef]

58. Kleinbaum, D.; Kupper, L.; Nizam, A.; Rosenberg, E. Applied Regression Analysis and Other Multivariable Methods, 5th ed.; Cengage Learning: Boston, MA, USA, 2013; p. 1072.

59. Chatterjee, S.; Simonoff, J.S. Handbook of Regression Analysis; John Wiley \& Sons Inc.: Hoboken, NJ, USA, 2013; p. 240.

60. Montgomery, D.C.; Peck, E.A.; Vining, G.G. Introduction to Linear Regression Analysis, 5th ed.; John Wiley \& Sons Inc.: Hoboken, NJ, USA, 2012; p. 645.

61. Yan, X.; Gang-Su, X. Linear Regression Analysis: Theory and Computing; World Scientific Publishing Company Pte. Limited: Singapore, 2009; p. 349.

62. Moran, P.A.P. The Interpretation of Statistical Maps. J. R. Stat. Soc. Ser. B Methodol. 1948, 10, 243-251. [CrossRef]

63. Moran, P.A.P. Notes on continuous stochastic phenomena. Biometrika 1950, 37, 17-23. [CrossRef]

64. Fotheringham, A.S. “The Problem of Spatial Autocorrelation” and Local Spatial Statistics. Geogr. Anal. 2009, 41, 398-403. [CrossRef]

65. Fizaine, F.; Voye, P.; Baumont, C. Does the Literature Support a High Willingness to Pay for Green Label Buildings? An Answer with Treatment of Publication Bias. Rev. D'écon. Polit. 2018, 128, 1013-1046. [CrossRef]

66. Mora-Garcia, R.T.; Cespedes-Lopez, M.F.; Perez-Sanchez, V.R.; Marti-Ciriquian, P.; Perez-Sanchez, J.C. Determinants of the Price of Housing in the Province of Alicante (Spain): Analysis Using Quantile Regression. Sustainability 2019, 11, 437. [CrossRef]

67. Perez-Sanchez, V.R.; Mora-Garcia, R.T.; Perez-Sanchez, J.C.; Cespedes-Lopez, M.F. The influence of the characteristics of second-hand properties on their asking prices: Evidence in the Alicante market. Inf. Constr. 2020, 72, 12. [CrossRef]

68. MITECO, Ministerio para la Transición Ecológica y el Reto Demográfico. Estado de la Certificación Energética de los Edificios ( $7^{\circ}$ Informe); Instituto para la Diversificación y Ahorro de la Energía: Madrid, Spain, 2018; p. 11. Available online: https://energia.gob.es/desarrollo/EficienciaEnergetica/CertificacionEnergetica/ Documentos/Documentos\%20informativos/informe-seguimiento-certificacion-energetica.pdf (accessed on 24 September 2019). 
69. Ramos, A.; Pérez-Alonso, A.; Silva, S. Valuing Energy Performance Certificates in the Portuguese Residential; Economics for Energy: Vigo, Spain, 2015; pp. 1028-3625. Available online: https://ideas.repec.org/p/efe/ wpaper/02-2015.html (accessed on 14 March 2019).

70. Cajias, M.; Piazolo, D. Green performs better: Energy efficiency and financial return on buildings. J. Corp. Real Estate 2013, 15, 53-72. [CrossRef]

71. García-Navarro, J.; González-Díaz, M.J.; Valdivieso, M. Assessment of construction costs and energy consumption resulting from house energy ratings in a residential building placed in Madrid: "Precost\&e Study". Inf. Constr. 2014, 66, e026. [CrossRef]

72. Kholodilin, K.A.; Mense, A.; Michelsen, C. The market value of energy efficiency in buildings and the mode of tenure. Urban Stud. 2017, 54, 3218-3238. [CrossRef]

73. Checa-Noguera, C.; Biere-Arenas, R. Approach to the influence of energy certifications on Real Estate values. ACE Archit. City Environ. 2017, 12, 165-190. [CrossRef]

74. Pascuas, R.P.; Paoletti, G.; Lollini, R. Impact and reliability of EPCs in the real estate market. Energy Procedia 2017, 140, 102-114. [CrossRef]

75. Marmolejo-Duarte, C.; Spairani-Berrio, S.; Del Moral-Ávila, C.; Delgado-Méndez, L. The Relevance of EPC Labels in the Spanish Residential Market: The Perspective of Real Estate Agents. Buildings 2020, 10, 27. [CrossRef]

76. Amecke, $\mathrm{H}$. The impact of energy performance certificates: A survey of German home owners. Energy Policy 2012, 46, 4-14. [CrossRef]

77. Ministerio para la Transición Ecológica y el Reto Demográfico; Instituto para la Diversificación y Ahorro de la Energía (IDAE). Programa de Ayudas Para la Rehabilitación Energética de Edificios Existentes (Programa PAREER II), Fondo Europeo de Desarrollo Regional (FEDER): 2014-2020; Instituto para la Diversificación y Ahorro de la Energía: Madrid, Spain.

78. Vicepresidencia Segunda y Conselleria de Vivienda y Arquitectura Bioclimática. Ayudas Plan RENHATA. Generalidad Valenciana; Diari Oficial de la Generalitat Valenciana: Valencia, Spain, 2020.

79. Igbinosa, S.O. Determinants of Residential Property Value in Nigeria-A Neural Network Approach. Int. Multidiscip. J. Ethiop. 2011, 5, 152-168. [CrossRef]

80. Selím, S. Determinants of House Prices in Turkey: A Hedonic Regression Model. Doğuş Üniv. Derg. 2008, 9, $65-76$.

81. Galvis, L.A.; Carrillo, B. Un índice de precios espacial para la vivienda urbana en Colombia: Una aplicación con métodos de emparejamiento. Rev. Econ. Rosario 2012, 16, 25-29.

82. Ferreira-Vaz, A.J. La Dimensión de la Subjetividad en la Formación del Valor Inmobiliario: Aplicación del Método de Análisis de Ecuaciones Estructurales al Mercado Residencial de Lisboa. Ph.D. Thesis, Universidad Politécnica de Madrid, Madrid, Spain, 2013. Available online: http://oa.upm.es/15577/ (accessed on 11 April 2018).

83. Yayar, R.; Demir, D. Hedonic estimation of housing market prices in Turkey. Erciyes Univ. J. Fac. Econ. Adm. Sci. 2014, 43, 67-82. [CrossRef]

84. Zahirovich-Herbert, V.; Gibler, K.M. The effect of new residential construction on housing prices. J. Hous. Econ. 2014, 26, 1-18. [CrossRef]

85. Chasco-Yrigoyen, C.; Gallo, J.L. The impact of objective and subjective measures of air quality and noise on house prices: A multilevel approach for downtown Madrid. Econ. Geogr. 2013, 89, 127-148. [CrossRef]

86. Fernández-Durán, L. Análisis del Impacto de los Aspectos Relativos a la Localización en el Precio de la Vivienda a Través de Técnicas de Soft Computing. Una Aplicación a la Ciudad de Valencia. Ph.D. Thesis, Universidad Politécnica de Valencia, Valencia, Spain, 2016. Available online: http://hdl.handle.net/10251/ 63253 (accessed on 15 February 2018).

87. Baudry, M.; Guengant, A.; Larribeau, S.; Leprince, M. Formation des prix immobiliers et consentements à payer pour une amélioration de l'environnement urbain: L'exemple rennais. Rev. D'Écon. Rég. Urb. 2009, 2, 369-411. [CrossRef]

88. Evangelista, R.; Ramalho, E.A.; Andrade-e-Silva, J. On the use of hedonic regression models to measure the effect of energy efficiency on residential property transaction prices: Evidence for Portugal and selected data issues. Energy Econ. 2020, 86, 104699. [CrossRef]

89. Humaran-Nahed, I.; Roca-Cladera, J. Towards a integrated measure of the location factor in the Real Estate valuation: The case of Mazatlan. ACE Arquit. Ciudad Entorno 2010, 13, 185-218. [CrossRef] 
90. Sagner, A. Determinantes del precio de viviendas en la región metropolitana de Chile. Trimest. Econ. 2011, 78, 813-839. [CrossRef]

91. Bohl, M.T.; Michels, W.; Oelgemöller, J. Determinanten von Wohnimmobilienpreisen: Das Beispiel der Stadt Münster. Jahrbuch Reg. 2012, 32, 193-208. [CrossRef]

92. Nicodemo, C.; Raya, J.M. Change in the distribution of house prices across spanish cities. Reg. Sci. Urban Econ. 2012, 42, 739-748. [CrossRef]

93. Kaya, A.; Atan, M. Determination of the factors that affect house prices in Turkey by using Hedonic Pricing Model. J. Bus. Econ. Financ. 2014, 3, 313-327.

94. Wen, H.; Bu, X.; Qin, Z. Spatial effect of lake landscape on housing price: A case study of the West Lake in Hangzhou, China. Habitat Int. 2014, 44, 31-40. [CrossRef]

95. Alkan, L. Housing market differentiation: The cases of Yenimahalle and Çankaya in Ankara. Int. J. Strateg. Prop. Manag. 2015, 19, 13-26. [CrossRef]

96. Fitch-Osuna, J.M. Sistema de valuación masiva de inmuebles para tasaciones. Contexto. Rev. Fac. Arquit. Univ. Autón. Nuevo León 2016, 10, 51-63.

97. Van-Dijk, D.; Siber, R.; Brouwer, R.; Logar, I.; Sanadgol, D. Valuing water resources in Switzerland using a hedonic price model. Water Resour. Res. 2016, 52, 3510-3526. [CrossRef]

98. Zambrano-Monserrate, M.A. Formation of housing rental prices in Machala, Ecuador: Hedonic prices analysis. Cuad. Econ. 2016, 39, 12-22. [CrossRef]

99. Keskin, B.; Watkins, C. Defining spatial housing submarkets: Exploring the case for expert delineated boundaries. Urban Stud. 2017, 54, 1446-1462. [CrossRef]

100. Lara-Pulido, J.A.; Estrada-Díaz, G.; Zentella-Gómez, J.C.; Guevara-Sanginés, A. The costs of urban expansion: An approach based on a hedonic price model in the Metropolitan Area of the Valley of Mexico. Estud. Demogr. Urbanos 2017, 32, 37-63. [CrossRef]

101. Park, J.; Lee, D.; Park, C.; Kim, H.; Jung, T.; Kim, S. Park accessibility impacts housing prices in Seoul. Sustainability 2017, 9, 185. [CrossRef]

102. Wen, H.; Xiao, Y.; Zhang, L. School district, education quality, and housing price: Evidence from a natural experiment in Hangzhou, China. Cities 2017, 66, 72-80. [CrossRef]

103. Xiao, Y.; Chen, X.; Li, Q.; Yu, X.; Chen, J.; Guo, J. Exploring Determinants of Housing Prices in Beijing: An Enhanced Hedonic Regression with Open Access POI Data. ISPRS Int. J. Geo-Inf. 2017, 6, 358. [CrossRef]

104. Li, R.; Li, H. Have housing prices gone with the smelly wind? Big data analysis on landfill in Hong Kong. Sustainability 2018, 10, 341. [CrossRef]

105. Lama-Santos, F.A.D. Determinación de las Cualidades de Valor en la Valoración de Bienes Inmuebles. La Influencia del nivel Socioeconómico en la Valoración de la Vivienda. Ph.D. Thesis, Universidad Politécnica de Valencia, Valencia, Spain, 2017. Available online: http://hdl.handle.net/10251/90526 (accessed on 6 March 2018).

106. Landajo, M.; Bilbao, C.; Bilbao, A. Nonparametric neural network modeling of hedonic prices in the housing market. Empir. Econ. 2012, 42, 987-1009. [CrossRef]

107. Núñez-Tabales, J.M.; Caridad-y-Ocerín, J.M.; Ceular-Villamandos, N.; Rey-Carmona, F.J. Obtención de precios implícitos para atributos determinantes en la valoración de una vivienda. Rev. Int. Adm. Finanz. 2012, 5, 41-54.

108. Núñez-Tabales, J.M.; Caridad-y-Ocerín, J.M.; Rey-Carmona, F.J. Artificial Neural Networks for predicting real estate prices. Rev. Métodos Cuantitativos Para Econ. Empresa 2013, 15, $29-44$.

109. Wen, H.; Xiao, Y.; Zhang, L. Spatial effect of river landscape on housing price: An empirical study on the Grand Canal in Hangzhou, China. Habitat Int. 2017, 63, 34-44. [CrossRef]

110. Yu, C.-M.; Chen, P.-F. House Prices, Mortgage Rate, and Policy: Megadata Analysis in Taipei. Sustainability 2018, 10, 926. [CrossRef]

111. Wu, H.; Jiao, H.; Yu, Y.; Li, Z.; Peng, Z.; Liu, L.; Zeng, Z. Influence Factors and Regression Model of Urban Housing Prices Based on Internet Open Access Data. Sustainability 2018, 10, 1676. [CrossRef]

112. Seo, D.; Chung, Y.; Kwon, Y. Price Determinants of Affordable Apartments in Vietnam: Toward the Public-Private Partnerships for Sustainable Housing Development. Sustainability 2018, 10, 197. [CrossRef]

113. Cebula, R.J. The hedonic pricing model applied to the housing market of the city of Savannah and its Savannah historic Landmark district. Rev. Reg. Stud. 2009, 39, 9-22. 
114. Stetler, K.M.; Venn, T.J.; Calkin, D.E. The effects of wildfire and environmental amenities on property values in northwest Montana, USA. Ecol. Econ. 2010, 69, 2233-2243. [CrossRef]

115. Duque, J.C.; Velásquez, H.; Agudelo, J. Public infrastructure and housing prices: An application of geographically weighted regression within the context of hedonic prices. Ecos Econ. 2011, 15, 95-122.

116. Moreno-Murrieta, R.E.; Alvarado-Lagunas, E. El entorno social y su impacto en el precio de la vivienda: Un análisis de precios hedónicos en el Área Metropolitana de Monterrey. Trayectorias Rev. Cienc. Soc. 2011, 14, 131-147.

117. Fernández-Durán, L.; Llorca-Ponce, A.; Valero-Cubas, S.; Botti-Navarro, V.J. Incidencia de la localización en el precio de la vivienda a través de un modelo de red neuronal artificial. Una aplicación a la ciudad de Valencia. Catastro 2012, 74, 7-25.

118. McGreal, W.S.; Taltavull-de-la-Paz, P. Implicit house prices: Variation over time and space in Spain. Urban Stud. 2013, 50, 2024-2043. [CrossRef]

119. Wen, H.; Goodman, A.C. Relationship between urban land price and housing price: Evidence from 21 provincial capitals in China. Habitat Int. 2013, 40, 9-17. [CrossRef]

120. Rey-Carmona, F.J. Alternativas Determinantes en Valoración de Inmuebles Urbanos. Ph.D. Thesis, Universidad de Córdoba, Córdoba, Spain, 2014. Available online: http://hdl.handle.net/10396/12473 (accessed on 11 April 2018).

121. Quispe-Villafuerte, A. Una aplicación del modelo de precios hedónicos al mercado de viviendas de Lima Metropolitana. Rev. Econ. Derecho 2012, 9, 85-121.

122. Núñez-Tabales, J.M.; Rey-Carmona, F.J.; Caridad-y-Ocerín, J.M. Artificial Intelligence (AI) techniques to analyze the determinants attributes in housing prices. Intell. Artif. 2016, 19, 23-38. [CrossRef]

123. Casas-del-Rosal, J.C. Métodos de Valoración Urbana. Ph.D. Thesis, Universidad de Córdoba, Córdoba, Spain, 2017. Available online: http://hdl.handle.net/10396/15417 (accessed on 11 April 2018).

124. Zhang, L.; Yi, Y. Quantile house price indices in Beijing. Reg. Sci. Urban Econ. 2017, 63, 85-96. [CrossRef]

125. Ezebilo, E. Evaluation of House Rent Prices and Their Affordability in Port Moresby, Papua New Guinea. Buildings 2017, 7, 114. [CrossRef]

126. Liu, J.-G.; Zhang, X.-L.; Wu, W.-P. Application of Fuzzy Neural Network for Real Estate Prediction. In Advances in Neural Networks-ISNN 2006; Springer: Berlin/Heidelberg, Germany, 2006; pp. 1187-1191. [CrossRef]

127. Keskin, B.; Dunning, R.; Watkins, C. Modelling the impact of earthquake activity on real estate values: A multi-level approach. J. Eur. Real Estate Res. 2017, 10, 73-90. [CrossRef]

128. Fitch-Osuna, J.M.; Soto-Canales, K.; Garza-Mendiola, R. Assessment of Urban-Environmental Quality. A Hedonic Modeling: San Nicolás de los Garza, Mexico. Estud. Demogr. Urbanos 2013, 28, 383-428. [CrossRef]

Publisher's Note: MDPI stays neutral with regard to jurisdictional claims in published maps and institutional affiliations.

(C) 2020 by the authors. Licensee MDPI, Basel, Switzerland. This article is an open access article distributed under the terms and conditions of the Creative Commons Attribution (CC BY) license (http://creativecommons.org/licenses/by/4.0/). 